\title{
A identificação de enquadramentos através da análise de correspondências: um modelo analítico aplicado à controvérsia das ações afirmativas raciais na imprensa
}

\begin{tabular}{c}
\hline \hline Luiz Augusto Campos \\
Instituto de Estudos Sociais e Políticos \\
Grupo de Estudos Multidisciplinares \\
da Ação Afirmativa (Gemaa) \\
Universidade Estadual do Rio de Janeiro \\
\hline \hline
\end{tabular}

\begin{abstract}
Resumo: Embora o conceito de enquadramento venha sendo intensivamente utilizado nos estudos de mídia, parece unânime a opinião de que seu emprego ainda é fluido demais para fundar um paradigma teórico. Contribui para isso a informalidade metodológica característica das rotinas tradicionalmente usadas para a identificação de enquadramentos. Diante dessa lacuna, este artigo propõe um protocolo para a identificação de enquadramentos midiáticos a partir da combinação de Programas Computacionais de Codificação Assistida de Dados Qualitativos (Caqdas, na sigla anglófona) com a técnica da Análise de Correspondências. Tal combinação permite explicitar os critérios que validam uma dada tipologia de enquadramentos sem, contudo, automatizar todo o processo. Para exemplificar os ganhos heurísticos dessa técnica, ela é aplicada a um corpus de textos sobre as ações afirmativas raciais nas universidades brasileiras publicados nos dois principais jornais brasileiros.
\end{abstract}

Palavras-chave: enquadramento; Caqdas; imprensa; análise de correspondências; ações afirmativas

Abstract: The concept of framing is intensively used in media studies. However, it is usually employed in a fractured way. In despite of its semantics inaccuracy, also contributes to these problems the lack of formal routines to identify media-frames. This article proposes a routine to framing identification based on the combination between Computer-Assisted Qualitative Data Analysis Software (Caqdas) and Correspondence Analysis techniques. Such mixed method could clarify the formalization of media-frames without mechanizing the full process. To exemplify the usefulness of this technique, it's applied to a corpus of journalistic texts about the affirmative action in Brazil.

Keywords: framing; Caqdas; press; correspondence analysis; affirmative action 


\section{Introdução ${ }^{1}$}

Desde a década de 1980, o conceito de enquadramento (framing) vem sendo intensivamente empregado em estudos do conteúdo midiático. Nomes como Gaye Tuchman (1978), Todd Gitlin (2003), William Gamson (1995), Robert Entman (1993), dentre muitos outros, já se converteram em clássicos da literatura especializada. Porém, mesmo dentre os partidários do conceito de enquadramento, parece unânime a opinião de que seu emprego é fluido e impreciso demais para fundar um paradigma teórico unificado (ENTMAn, 1993, p. 51; GAMSON, 2001, p. x; SheufELE, 1999, p. 103). Há quem defenda até que a crescente popularidade do conceito nas análises da mídia "caminha de mãos dadas com a considerável inconsistência da sua aplicação" (VREESE, 2005, p. 51).

De fato, se uma lista com as acepções cunhadas para o termo fosse submetida a um leitor leigo, provavelmente ele se sentiria contemplando um dicionário de sinônimos, no qual se lê uma coleção de definições muito semelhantes para um mesmo termo. Enquanto alguns autores dizem que enquadramentos são "princípios organizadores da realidade" (REESE, 2001, p. 11), outros preferem defini-los como "padrões de cognição" (GITLIN, 2003, p. 7). Se para uns "enquadrar" é basicamente uma atividade perceptiva, em que o ator "enfatiza" ou "salienta" determinadas partes da realidade (ENTMAN, 1993, p. 52; GITLIN, 2003, p. 7), para outros trata-se de uma atividade construtiva, ou um meio de "constituir simbolicamente a estrutura do mundo" (REESE, 2001, p. 11).

Entretanto, a despeito dessa variação terminológica, o núcleo semântico que distingue o conceito permanece praticamente intocado de definição para definição. Ao que parece, não é propriamente a fluidez conceitual que tem gerado imprecisões, mas a ausência de técnicas capazes de tornar mais clara e rigorosa a identificação do que cada autor eventualmente chama de "enquadramento". Nos estudos de mídia, a identificação de enquadramentos midiáticos costuma seguir uma rotina informal, baseada na identificação, por semelhança e diferença, das retóricas e dos conteúdos mais recorrentes para lidar com um tema em um dado corpus linguístico (TANKARD JR., 2001, p. 97).

Embora amplamente empregada, tal rotina costuma levar à construção de tipologias de enquadramentos a partir de parâmetros mais ou menos arbitrários que, não raro, expressam mais a forma como um investigador "enquadra" uma temática do que o modo como os atores estudados o fazem. De fato, é impossível para um estudioso identificar enquadramentos midiáticos sem projetar em alguma medida suas próprias perspectivas sobre o conteúdo estudado. Por outro lado, é possível conferir maior objetividade a tais procedimentos caso os critérios utilizados para formalizar tipologias sejam minimamente explicitados e, assim, submetidos ao escrutínio intersubjetivo.

Com o avanço de algumas técnicas estatísticas e informáticas para a exploração de volumes grandes de textos, surgiram recentemente algumas propostas metodológicas que prometem a automatização da análise de conteúdos discursivos como, por exemplo, análise fatorial, análise de clusters ou a análise de classes latentes (KOENIG, 2005). Entretanto, alguns estudiosos dessas possibilidades metodológicas parecem nutrir esperanças de que esses instrumentos computacionais e

\footnotetext{
1 Este artigo é uma versão remodelada de um dos capítulos da minha tese de doutorado. Gostaria de agradecer a João Feres Jr. pela orientação durante a pesquisa e a Thyago Simas de Oliveira pelo inestimável auxílio técnico. Agradeço também a Larissa Soares, Pedro Ramos, Verônica Toste Daflon e a toda equipe do Grupo de Estudos Multidisciplinares da Ação Afirmativa (Gemaa lesp) pelo empenho na codificação dos textos. Também agradeço ao parecerista anônimo pelos comentários e sugestões.
} 
CAMPOS, L. A. A identificação de enquadramentos através da análise de...

estatísticos possam automatizar quase totalmente a formalização de enquadramentos, dispensando ou limitando substantivamente os juízos interpretativos do investigador. Mas, ainda que tais técnicas tenham um potencial enorme e pouco explorado, parece exagerado supor que a interpretação humana possa - ou mesmo deva - ser substituída por instrumentos que, a rigor, só funcionam quando orientados pela subjetividade humana.

Diante disso, este artigo apresenta um modelo analítico que visa rotinizar a identificação de enquadramentos sem, contudo, automatizá-la completamente. Parte-se do pressuposto de que a validação de uma dada tipologia de enquadramentos deva ser precedida de uma identificação das partes que compõem cada um deles. Uma vez identificados tais elementos, é possível recorrer a técnicas estatísticas que exponham como eles são articulados em notícias, colunas, artigos, editoriais etc. Esses mapas cognitivos, por seu turno, servem como guias para a distinção de determinados enquadramentos padronizados.

Logo, proponho uma rotina de identificação de enquadramentos midiáticos baseada em três etapas: i) a identificação da maior pluralidade possível dos elementos de assinatura, recorrentes na cobertura midiática de um dado tema, por codificadores treinados e auxiliada por Programas Computacionais de Codificação Assistida (Caqdas, na sigla anglófona); ii) a mensuração da coocorrência desses elementos nos textos publicados através da técnica de Análise de Correspondências Simples (ACS); iii) e a conflação dos elementos de assinatura que mais coocorrem nos textos em agrupamentos comuns (enquadramentos).

Para demonstrar a pertinência desse método, ele foi aplicado a um conjunto de textos publicados pela imprensa sobre o tema das ações afirmativas raciais no ensino superior brasileiro. 0 levantamento foi realizado pela equipe do Grupo de Estudos Multidisciplinares da Ação Afirmativa (Gemaa) e coordenado pelo professor João Feres Júnior. A pesquisa abrangeu todos os textos publicados pelos jornais O Globo e Folha de S. Paulo entre 2001 e 2009 e que versavam sobre a temática das ações afirmativas raciais no ensino superior brasileiro.

O ano de 2001 foi definido como início do recorte porque ele marca a fixação do tema na agenda de debate midiático. Isso se deu principalmente a partir da III Conferência Mundial contra o Racismo, a Discriminação Racial, a Xenofobia e as Formas Correlatas de Intolerância, ocorrida entre os dias 31 de agosto e 7 de setembro na cidade sul-africana de Durban. Foi durante a alcunhada Conferência de Durban que a delegação diplomática nacional declarou oficialmente a intenção do governo federal em implementar políticas de ação afirmativa racial no Brasil (ALVES, 2002). Mais do que isso, é nesse período que o então presidente da República, Fernando Henrique Cardoso, declarou num programa de televisão dominical o apoio a essa política (PEREIRA, 2003), evento que colocou o tema na pauta do debate midiático.

O ano de 2009 marcou o fim de um ciclo na cobertura das ações afirmativas raciais. É a partir dele que a frequência do tema nas páginas dos jornais diminui e se estabiliza, indicando um momento de rotinização da cobertura. Isso ocorre em grande medida devido à proposição de uma Ação de Descumprimento de Preceito Fundamental (ADPF) no Supremo Tribunal Federal (STF) alegando a inconstitucionalidade da política. Essa "judicialização da controvérsia" não fez com que o tema desaparecesse dos jornais, mas diminuiu muito o espaço concedido ao debate da ação afirmativa racial. 
A escolha dos jornais incluídos no corpus da pesquisa obedeceu a dois critérios: tipo de periódico e circulação nacional. No período estudado, O Globo e Folha de S. Paulo foram os dois jornais standards ${ }^{2}$ com maior circulação média nacional. Segundo o Instituto Verificador de Circulação (IVC), a Folha de S. Paulo colocou em circulação uma média de 312 mil exemplares por dia entre 2002 e 2009, contra 268 mil de $O$ Globo. Porém, mais importante que a circulação é o fato de os dois jornais estudados serem exemplares do que a literatura anglófona chama de quality paper (HALLIN; MANCINI, 2004, p. 25), ou seja, são jornais que buscam se afastar dos periódicos mais populares ao: i) mirarem num leitorado pertencente às elites políticas, econômicas e intelectuais, ii) empregarem mão de obra profissionalizada em suas redações, iii) conferirem um espaço relativamente maior ao noticiário político em comparação a outros nichos temáticos e iv) obterem a maior parte de seus lucros da publicidade em suas páginas.

No total, o corpus compilou 1.831 textos de diferentes tipos, sendo publicados 944 em O Globo e 887 na Folha de S. Paulo. Ao todo, foram compiladas 754 reportagens, 124 entrevistas, 206 colunas fixas, 118 editoriais, 221 artigos, 76 boxes ou notas e 332 cartas de leitores. Vale destacar que esse levantamento analisou todo o universo de textos incluídos no recorte de pesquisa e não apenas uma amostra representativa deles.

O que se segue está dividido em quatro partes. A próxima seção faz um resumo da história do conceito de enquadramento com o intuito de reter os traços mais recorrentes das definições dadas ao termo. Em seguida, discute-se como a construção de uma edição de jornal envolve níveis de enquadramentos distintos, os quais devem ser analiticamente diferenciados quando se pretende identificar quadros midiáticos. A terceira seção apresenta os resultados obtidos com a aplicação da rotina metodológica aqui proposta. A última seção resume algumas conclusões sobre as potencialidades e os limites da técnica aqui proposta.

\section{0 conceito de enquadramento}

O conceito de enquadramento, instrumentalizado por estudiosos da mídia, tem sua origem ligada a diferentes teorias desenvolvidas na intersecção entre psicologia social e sociologia. O psicólogo social Gregory Bateson é frequentemente considerado o primeiro a empregar o termo com um conteúdo próximo ao que ele tem hoje nos estudos de mídia. Interessado em entender a comunicação entre psiquiatra e paciente, Bateson destaca que os significados trocados em uma sessão clínica dependem da forma como ambos implicitamente caracterizam a situação em que se encontram (BATESON, 1987, p. 138). Antecipando o que um ano depois John Austin chamaria de "dimensão ilocucionária dos atos de fala" (AUSTIN, 1962, p. 106), Bateson ressalta a importância dos sinais metalinguísticos que trocamos quando interagimos e como eles são capazes de redefinir o conteúdo efetivamente comunicado entre duas ou mais pessoas.

Quando dois seres vivos brincam, por exemplo, eles transmitem sinais capazes de avisar que as ações performadas na situação não significam o que elas usualmente significariam. Para Bateson, isso fica particularmente evidente quando "brincamos de brigar", situações em que "uma mordidela denota

\footnotetext{
2 Em comparação com os jornais classificados pela ANJ como "tabloides", os jornais "standards" são fisicamente maiores, publicados numa frequência igual ou maior, além de em geral veicularem mais conteúdo e menos publicidade em termos relativos. Para mais informações, cf. <www.anj.org.br>. Acesso em: 9 out. 2012.
} 
CAMPOS, L. A. A identificação de enquadramentos através da análise de...

uma mordida, mas sem denotar o que seria denotado pela mordida" (BATESON, 1987, p. 139). A partir disso, Bateson defende que todo processo comunicativo depende da forma como os envolvidos definem a interação em que se encontram, isto é, como aqueles que interagem definem um "enquadramento" (framing) para a situação em questão (BATESON, 1987, p. 142).

Em Frame analysis (1986), Erving Goffman recorre à ideia batesoniana de enquadramento para investigar em quais circunstâncias os indivíduos tomam uma determinada situação como real. Mais do que definir filosoficamente como acessamos o real, Goffman retoma uma série de questionamentos sobre a maneira como os indivíduos definem a realidade, selecionando apenas alguns dos seus elementos e descartando outros (GOFFMAN, 1986, p. 2.4). Para ele, a definição de uma situação é feita com base em "princípios de organização que governam eventos, chamados aqui de enquadramentos [frames]" (GofFMAN, 1986, p. 10). O objetivo de uma análise de enquadramentos seria "isolar alguns quadros de entendimentos básicos [basics frameworks of understandings] disponíveis na nossa sociedade para dar sentido a eventos e analisar vulnerabilidades especiais a que esses quadros de referência estão sujeitos" (GOFFMAN, 1986, p. 10).

Na esteira dos trabalhos escritos por Goffman durante a década de 1970, os psicólogos sociais Daniel Kahneman e Amos Tversky (1981) desenvolveram experimentos para determinar até que ponto enquadramentos diferentes para uma mesma situação levam os atores a construir opiniões distintas ou adotar condutas diferentes perante ela. Para isolar esse "efeito-enquadramento", os autores organizaram uma série de experimentos - que renderam a Kahneman o Prêmio Nobel de Economia - em que pediam para que um grupo de indivíduos definisse qual a melhor solução dentro de um rol predeterminado para um conjunto de problemas hipotéticos. Em um desses experimentos, Kahneman e Tversky perguntam para 155 indivíduos qual programa de salvação seria preferível caso 600 habitantes de uma cidade hipotética fossem contaminados por uma epidemia desconhecida. Abstraindo algumas nuances narrativas, duas alternativas eram oferecidas: em uma, 400 pessoas morreriam, enquanto na outra 200 pessoas seriam salvas. Embora os resultados das alternativas sejam idênticos em termos de mortes (em um grupo de 600, a morte de 400 pessoas é igual à sobrevivência de 200), a opção apresentada em termos de vidas salvas teve três vezes mais suporte que aquela apresentada em termos de vidas sacrificadas (TVERSkY; KAHNEMAN, 1981, p. 453). Para os autores, os resultados de todos os experimentos mostraram que "mudanças aparentemente sem consequência na formulação em problemas que exigem escolha causaram mudanças significativas nas preferências dos indivíduos" (TVERSKY; KAHNEMAN, 1981, p. 457).

Utilizado para fins diversos, a ideia de enquadramento discutida por esses autores remete a um conjunto de fenômenos similares. Ela quase sempre aponta para o modo como os indivíduos dotam de sentido uma situação, a partir de matrizes interpretativas previamente formadas, e como tais matizes podem engendrar mudanças comportamentais. Todos eles também destacam a capacidade dos indivíduos em manipular algumas de suas expressões, verbais ou não, para persuadir aqueles com quem interagem de um dado enquadramento para uma situação. Tais manipulações, no entanto, não constroem necessariamente uma visão falsa ou mentirosa da realidade, mas apenas enfatizam determinados elementos ou possibilidades desta em detrimento de outros.

Na passagem para os anos 1980, a noção de enquadramento foi mobilizada por investigadores que objetivavam se distanciar de alguns paradigmas tradicionais dos estudos de mídia. De um lado, 
esses investigadores buscavam romper com o que ficou conhecido como "teoria hipodérmica dos meios de comunicação", corrente que tratava os efeitos da mídia partindo de uma visão pavloviana do consumidor de notícias, reduzido a um receptor apático e passivo das mensagens midiáticas (cf. Lasswell, 2011). De outro lado, buscavam romper também com a tradição inaugurada por Paul Lazarsfeld, a qual se servia de amplos surveys de opinião para afirmar que a mídia tem pouca ou nenhuma influência na formação da opinião pública (LAZARSFELD; BERELSON; GAUDET, 1944).

A crítica a essas duas correntes pelos partidários da noção de enquadramento se deu basicamente em três frentes. Em primeiro lugar, o conceito de enquadramento foi utilizado para contestar a ideia de objetividade midiática, subjacente tanto aos trabalhos de Lasswell quanto às pesquisas de Lazarsfeld. Ainda no início da década de 1970, Gaye Tuchman (1973) já manifestava seu incômodo com as investigações que avaliavam a atuação da mídia a partir das noções de "distorção" ou "viés" (Tuchman, 1973, p. 129). Na esteira de Tuchman, Robert Hackett propõe que, em vez de investigar se a mídia distorce ou não o real, seria mais relevante apreender o tipo de "orientação estruturada" que marca as coberturas jornalísticas (HACKETT, 1984).

Aos poucos, o conceito de enquadramento se impõe como um instrumento contrário ao empirismo ingênuo dos paradigmas pregressos, o qual possibilitaria captar a orientação estruturada da mídia. É nesse sentido que Tuchman instrumentaliza a ideia goffmaniana de enquadramento no seu livro Making news (TUCHMAN, 1978). Logo na abertura do texto, ela sustenta a ideia de que as notícias são "uma janela para o mundo" e, portanto, enquadram a realidade a que temos acesso (TUCHMAN, 1978, p.1). Ao usar o termo "enquadramento", Tuchman quer evidenciar que valores jornalísticos como neutralidade, imparcialidade e objetividade devem ser entendidos como parâmetros que ajudam o jornalista a definir as "redes de facticidade", isto é, o que conta ou o que não conta como fato para a mídia (TUCHMAN, 1978, p. 183).

Em segundo lugar, os autores que mobilizam a categoria defendem, especificamente contra Lasswell, a ideia de que a mídia manipula a audiência a seu bel-prazer. Parte-se da premissa de que os efeitos da mídia sobre a audiência são muito mais complexos do que aqueles medidos pelo cientista político estadunidense. Isso não quer dizer, porém, que a mídia tenha pouca ou nenhuma influência sobre como uma audiência pensa determinados temas. Como dizia Cohen, mesmo que a mídia não seja capaz de dizer às pessoas o que pensar, ela parece ser eficiente ao dizer sobre o que elas devem pensar [hipótese do agenda-setting] e, mormente, como elas devem pensar sobre tais assuntos [hipótese do enquadramento] (COHEN apud MCCOMBS; SHAW, 1972, p. 177). Baseado nessa premissa, muitos autores tentam demonstrar que, mesmo quando uma audiência não incorpora as interpretações difundidas pela mídia, os enquadramentos midiáticos fornecem os mapas cognitivos que utilizamos para refletir sobre problemáticas públicas.

Um exemplo desse uso do conceito pode ser encontrado no estudo da construção da imagem midiática do movimento estudantil estadunidense da década de 1960, feito por Todd Gitlin (2003). Esse artigo propõe que enquadramentos devem ser entendidos como "padrões sistemáticos de conhecimento, interpretação e apresentação, de seleção, ênfase e exclusão, pelos quais manipuladores de símbolos rotineiramente organizam discurso, seja verbal ou visual" (GITLIN, 2003, p. 7, grifo no original). Note-se que tais enquadramentos importam, não por dizerem o que uma audiência deve pensar, mas por estabelecerem o modo "natural" de pensar sobre uma dada realidade (GITLIN, 2003, p. 10). 
CAMPOS, L. A. A identificação de enquadramentos através da análise de...

Em terceiro lugar, os estudiosos dos enquadramentos argumentam que os receptores das mensagens midiáticas não podem ser vistos como seres autômatos, como sugeriam de diferentes perspectivas Lasswell e Lazarsfeld. A audiência retrabalha as mensagens midiáticas e, por isso, os estudos de mídia não poderiam se centrar apenas no que é publicado para determinar o conteúdo da opinião pública. É aqui que sociólogos como William Gamson sugerem o uso de grupos focais para determinar de que modo uma dada audiência reenquadra os enquadramentos difundidos pela imprensa (GAMSON, 1995; GAMSON; ModIGliAnI, 1987). Baseado nisso, Gamson tenta estabelecer em Talking politics (1995) a maneira como alguns trabalhadores estadunidenses deglutiam os enquadramentos disponibilizados pela mídia sobre quatro grandes polêmicas do período. Para tal, ele compatibilizou uma análise dos conteúdos midiáticos sobre tais assuntos com os resultados de alguns grupos focais em que eles eram discutidos. Ele conclui que o público possui graus variáveis de independência cognitiva em relação à mídia, a depender, por exemplo, da experiência que as pessoas têm com o problema em discussão e da sabedoria popular disponível sobre ele (GAMSON, 1995, p. 176).

A despeito das diferentes apropriações da ideia de enquadramento, há uma continuidade nos interesses analíticos de autores como Tuchman, Gitlin e Gamson. No entanto, é possível perceber que cada uma das definições propostas insere perspectivas particulares sobre como os enquadramentos operam. Enquanto Tuchman enfatiza o caráter construtivo dos enquadramentos, Gitlin tende a focar o caráter rotinizado destes. Enquanto Gamson recorre ao conceito para apreender de que modo uma audiência reenquadra as interpretações difundidas pela mídia, Tuchman o utiliza para apreender os processos de produção da notícia.

É apenas a partir de um opúsculo publicado por Robert Entman já na década de 1990 que esforços de uniformização do conceito começam a ganhar espaço nessa literatura. Para Entman, a noção de enquadramento, tal qual usada pelos estudos de mídia, aponta para o fato de que as mensagens jornalísticas costumam definir problemas, diagnosticar suas causas, sugerir julgamentos morais sobre eles e, eventualmente, sugerir remédios para sua solução (ENTMAN, 1993, p. 52). Nos seus termos:

\footnotetext{
Enquadrar é selecionar alguns aspectos da realidade percebida e torná-los salientes em um texto comunicativo, de modo a promover uma definição particular de um problema, interpretação causal, avaliação moral ou recomendação de tratamento para o item descrito (ENTMAN, 1993, p. 52).
}

O conceito de enquadramento também chama atenção para o fato de que "a presença de enquadramentos, detectada por pesquisadores, não garante sua influência no pensamento da audiência" (ENTMAN, 1993, p. 53), embora permita que tal influência seja estimada. Não é nosso objetivo aqui traçar uma história exaustiva do conceito de enquadramento, muito menos das tentativas de unificação do paradigma $^{3}$. Queremos apenas destacar as linhas gerais que caracterizam a categoria e, mormente, sublinhar que os esforços envidados para unificar o seu significado não têm sido acompanhados de um empenho semelhante em definir um protocolo para a formalização de enquadramentos.

Como já foi dito, a identificação de enquadramentos midiáticos costuma seguir uma rotina informal. A partir de uma amostra dos textos de um dado corpus, um pesquisador identifica por

\footnotetext{
${ }^{3}$ Discussões sobre a história do conceito e os diferentes modos como ele é empregado podem ser encontradas em Scheufele (2000); Gandy Jr. (2001); Porto (2004); Mendonça e Simões (2012), dentre outros.
} 
semelhança e diferença as retóricas e os conteúdos mais recorrentes para lidar com um dado tema. Em seguida, essas retóricas e esses conteúdos mais recorrentes são formalizados em uma lista de códigos que são aplicados aos demais textos do corpus em questão. Embora não seja forçoso, muitos pesquisadores buscam também estabelecer o espaço que um dado veículo de comunicação confere a determinados enquadramentos ou a recorrência deles em um dado período (TANKARD JR., 2001, p. 97).

Não obstante a sistematização de enquadramentos dependa de critérios interpretativos necessariamente subjetivos, essa rotina informal coloca alguns problemas. Em primeiro lugar, quase nunca são explicitados os critérios que levaram à construção de uma dada tipologia de enquadramentos interpretativos. Em geral, essas tipologias são construídas a partir de parâmetros mais ou menos arbitrários e, por isso, expressam mais a forma como o investigador em questão enquadra a temática estudada do que o modo como os atores estudados o fazem.

Muitos desses problemas são inescapáveis. Goffman tinha razão quando afirmou que "as discussões acerca do enquadramento inevitavelmente levam a questões sobre o estatuto da discussão em si, pois os termos aqui aplicados ao que é analisado podem ser aplicados à análise também" (GoFFMAN, 1986, p. 11). Ou seja, uma tipologia de enquadramentos pode ser considerada, ela própria, um novo enquadramento para outros enquadramentos. No entanto, isso não significa que é impossível conferir mais objetividade à formalização de enquadramentos, mormente a partir da explicitação dos critérios utilizados para construir tais tipologias. Quanto mais claros forem esses critérios, mais abertos eles serão ao julgamento intersubjetivo.

Na tentativa de contornar esses obstáculos, proponho aqui uma rotina de identificação de enquadramentos midiáticos baseada em três etapas: i) a identificação da maior pluralidade possível dos elementos de assinatura recorrentes na cobertura midiática de um dado tema; ii) a mensuração da coocorrência desses elementos nos textos publicados; iii) e a fusão dos elementos que mais coocorrem em agrupamentos comuns. A combinação dessas três etapas só foi possível a partir do uso simultâneo de Programas Computacionais de Codificação Assistida de Dados Qualitativos (Caqdas, na sigla anglófona) com a Análise de Correspondências Simples (ACS), técnica estatística de exposição de dados categóricos. Todavia, antes de discutir tal protocolo metodológico, faz-se necessário apresentar algumas ponderações sobre o modo como o conceito de enquadramento foi operacionalizado aqui.

\section{Níveis de enquadramento}

Como vimos, a ideia de enquadramento remete a uma miríade de práticas muito distintas. Por outro lado, se a amplitude semântica do conceito gera imprecisões, ela também possibilita abarcar em uma mesma categoria os inúmeros procedimentos presentes no processo de construção simbólica da realidade pela mídia. Por isso, antes de discutir os critérios para a formalização de enquadramentos, é necessário entender os diferentes níveis em que os processos de enquadramento operam dentro de uma redação jornalística.

Para melhor entender o que chamo de níveis de enquadramento, tomemos como exemplo um dos enquadramentos mais comuns na cobertura jornalística de processos eleitorais: o alcunhado "enquadramento corrida de cavalos". Grosso modo, esse enquadramento faz referência à forma como veículos de mídia cobrem determinados momentos eleitorais a partir dos mesmos critérios narrativos empregados em disputas esportivas, reduzindo as eleições a uma mera competição por votos. Mas, a 
CAMPOS, L. A. A identificação de enquadramentos através da análise de...

despeito da grande quantidade de autores que identificam tal enquadramento em pesquisas distintas (BAKER, 2001; CAPPELla; JAmieson, 1997; Hallin, 1994), ele abarca padrões formais e conteúdos textuais muito diversos. A recorrente publicação dos resultados quantitativos de pesquisas eleitorais, a adoção de uma retórica da disputa nas reportagens, a divisão da seção opinativa dos jornais entre defensores de cada um dos políticos em campanha, a desconsideração dos programas de cada candidato etc., todas podem ser expressões comuns do enquadramento corrida de cavalos.

Cada um desses exemplos remete a etapas diversas do processo de confecção de uma edição de jornal e refletem as escolhas de estratos diferentes de trabalhadores de uma redação. A adoção de uma retórica da disputa em uma dada reportagem, por exemplo, tende a ser definida, ao menos em tese, pelo jornalista que a escreve. É verdade que, na maioria das redações, os editores têm o poder de impor uma retórica às matérias que, a rigor, eles não escreveram. Contudo, é preciso levar em conta que a adoção de uma retórica da disputa se dá em um nível estritamente textual. Já a divisão da seção de opiniões em duas alas, representativas dos candidatos em disputa, costuma refletir uma escolha dos editores do periódico.

Assim, a convocação de determinados colaboradores, a definição dos colunistas fixos, o estabelecimento de uma proporção entre textos opinativos e reportagens, por exemplo, formam enquadramentos distintos daqueles presentes em uma notícia ou em um texto opinativo. Chamo esses princípios de organização de enquadramentos editoriais. Quase sempre, os enquadramentos editoriais são mais implícitos e têm efeitos - se os têm - no longo prazo. Outra particularidade é que eles expressam mais as rotinas de organização e produção da notícia do que as características específicas de uma temática. $\mathrm{O}$ enquadramento corrida de cavalos pode ser aplicado a uma série de temáticas diversas, mas expressa e radicaliza o mandamento jornalístico de "sempre se ouvir os dois lados de toda questão" (TUCHMAN, 1972). Sendo assim, a influência de um enquadramento editorial reside mais na sua capacidade de orientar o processo comunicativo entre o leitor em um dado conteúdo do que no conteúdo efetivamente comunicado.

Por tudo isso, enquadramentos editoriais dificilmente são captáveis levando em conta apenas o conteúdo textual de uma cobertura. É preciso considerar também o perfil de quem é convocado a opinar no jornal, em que seções se publicam os textos sobre um dado tema etc. A adoção de uma retórica da disputa, por outro lado, expressa outro tipo de enquadramento que tem a ver com os conteúdos explicitamente presentes em um texto midiático. Indícios textuais do enquadramento corrida de cavalos podem ser facilmente encontrados quando as matérias jornalísticas utilizam slogans e vocabulário próprios dos esportes, como "a disputa este ano está acirrada", "o candidato $A$ tem muitas chances de ultrapassar o candidato $B$ " etc. Isoladamente, porém, essas expressões não são suficientes para que se ateste a existência desse padrão na cobertura. Elas funcionam apenas como "elementos de assinatura" de um enquadramento e, portanto, embora insinuem que ele está presente, não servem individualmente como prova disso.

O enquadramento corrida de cavalos é um enquadramento próprio das rotinas jornalísticas e editoriais. A mídia, no entanto, é uma importante difusora de enquadramentos interpretativos ligados a um tema em particular. Ainda que os editores e jornalistas sejam atores fundamentais na difusão desses enquadramentos interpretativos, eles costumam ser produzidos fora das redações e por atores sociais diversos. E, visto que o jornalismo moderno se pretende imparcial em face das diversas temáticas 
públicas, os enquadramentos interpretativos não costumam ser produzidos diretamente por repórteres, mas sim por colunistas de opinião ou informantes citados em reportagens.

Por isso, é importante fazer uma distinção entre enquadramentos editoriais, enquadramentos noticiosos e enquadramentos interpretativos. Os enquadramentos editoriais abarcam o conjunto de critérios editoriais de seleção, ênfase e distribuição dos textos sobre um dado tema no interior de cada edição publicada. Tais enquadramentos costumam expressar as rotinas de produção e organização da notícia, as quais traduzem para a prática jornalística os princípios éticos que norteiam a atuação pública da imprensa. Já enquadramentos noticiosos têm a ver com os princípios de seleção e ênfase próprios da redação de uma notícia por um jornalista profissional. Como nota Mauro Porto, o enquadramento noticioso é aquilo que no jargão dos jornalistas "seria o 'ângulo da notícia', o ponto de vista adotado pelo texto noticioso que destaca certos elementos de uma realidade em detrimento de outros" (PORTO, 2004, p. 91). Enquadramentos interpretativos, por sua vez, têm a ver com definições de uma dada realidade que objetivam basicamente induzir uma avaliação de um dado tema ou evento:

\footnotetext{
Enquadramentos interpretativos são padrões de interpretação que promovem uma avaliação particular de temas e/ou eventos políticos, incluindo definições de problemas, avaliações sobre causas e responsabilidades, recomendações de tratamento etc. Estas interpretações são promovidas por atores sociais diversos, incluindo representantes do governo, partidos políticos, movimentos sociais, sindicatos, associações profissionais. Embora os jornalistas também contribuam com seus próprios enquadramentos interpretativos ao produzir notícias, este tipo de enquadramento tem origem geralmente em atores sociais e políticos externos à prática jornalística. Trata-se aqui de interpretações oriundas de um contexto mais amplo que podem ser incorporadas ou não pela mídia (PORTO, 2004, p. 96).
}

Feitas essas ressalvas, passemos à análise pormenorizada da técnica de identificação de enquadramentos aqui proposta.

\section{Formalizando enquadramentos}

A identificação dos elementos de assinatura

Raramente os estudos de mídia apresentam evidências capazes de demonstrar que uma dada tipologia de enquadramentos não é apenas uma projeção da mente do analista. E como boa parte das problemáticas que interessam à imprensa envolve controvérsias e conflitos político-morais, é natural que cada investigador costume ter sua própria posição em relação ao tema estudado, isto é, seu próprio enquadramento.

De acordo com Gamson e Modigliani, dificuldades como a mencionada acima podem ser parcialmente contornadas caso a identificação dos enquadramentos respeite ao máximo a linguagem utilizada por aqueles que os advogam (GAMSON; ModIGLIANI, 1987, p. 144). Contudo, é difícil crer que a lista com apenas sete enquadramentos interpretativos sobre as ações afirmativas, fornecida pelos autores, respeite a linguagem dos contendores envolvidos na complexa e longa controvérsia estadunidense em torno das ações afirmativas. Para afastar esse tipo de crítica, é preciso identificar a maior pluralidade possível de frases padronizadas e slogans mencionados por aqueles que esposam uma 
visão sobre um dado tema. Esses slogans indicam os elementos de assinatura ou subenquadramentos que fazem parte de um enquadramento mais amplo. Embora essa lista nunca seja capaz de esgotar os subenquadramentos existentes, ela provavelmente será tão mais inclusiva quanto mais elementos de assinatura considerar.

Diante das dimensões do corpus aqui analisado, técnicas distintas de análise de conteúdo tiveram de ser compatibilizadas. Toda a codificação foi feita no âmbito do Grupo de Estudos Multidisciplinares da Ação Afirmativa (Gemaa). A codificação contou com o empenho de cinco codificadores, os quais ficaram responsáveis pela interpretação e codificação de cotas do corpus definidas aleatoriamente. De um lado, tomou-se cada texto como uma unidade de análise e a partir da ferramenta de análise estatística Sphinx Léxica, formou-se uma base de dados com as características mais importantes de cada um deles. Paralelamente, procedeu-se a uma codificação dos textos que considerasse cada parágrafo uma unidade de análise. O objetivo dessa etapa foi captar a maior pluralidade possível de argumentos em torno das ações afirmativas raciais. Essa codificação por trecho foi feita utilizando o programa de análise hermenêutica Atlas Ti. A identificação dos argumentos em relação às ações afirmativas raciais buscou ser o mais fiel possível aos termos utilizados pelos textos. Por isso, quase uma centena de argumentos-chave foram tipificados (Quadro 1).

Em um primeiro momento, buscou-se estabelecer uma lista inicial de argumentações em torno das ações afirmativas raciais. Em um segundo momento, foi feita uma leitura preliminar dos textos da imprensa. Em um terceiro momento, os codificadores iniciaram o processo de aplicação dos argumentos codificados aos parágrafos e, quando era o caso, trouxeram para a discussão em grupo as situações em que a aplicação apresentava problemas. Para contornar esses problemas de encaixe, novos códigos argumentativos eram criados. As discussões em grupo foram fundamentais para estabilizar os significados de cada argumento codificado, mas, sobretudo, para unificar o entendimento da equipe em torno de cada código. 
Quadro 1

\section{Lista de argumentos codificados}

\begin{tabular}{|c|c|}
\hline ontrários & rgumentos favoráveis \\
\hline 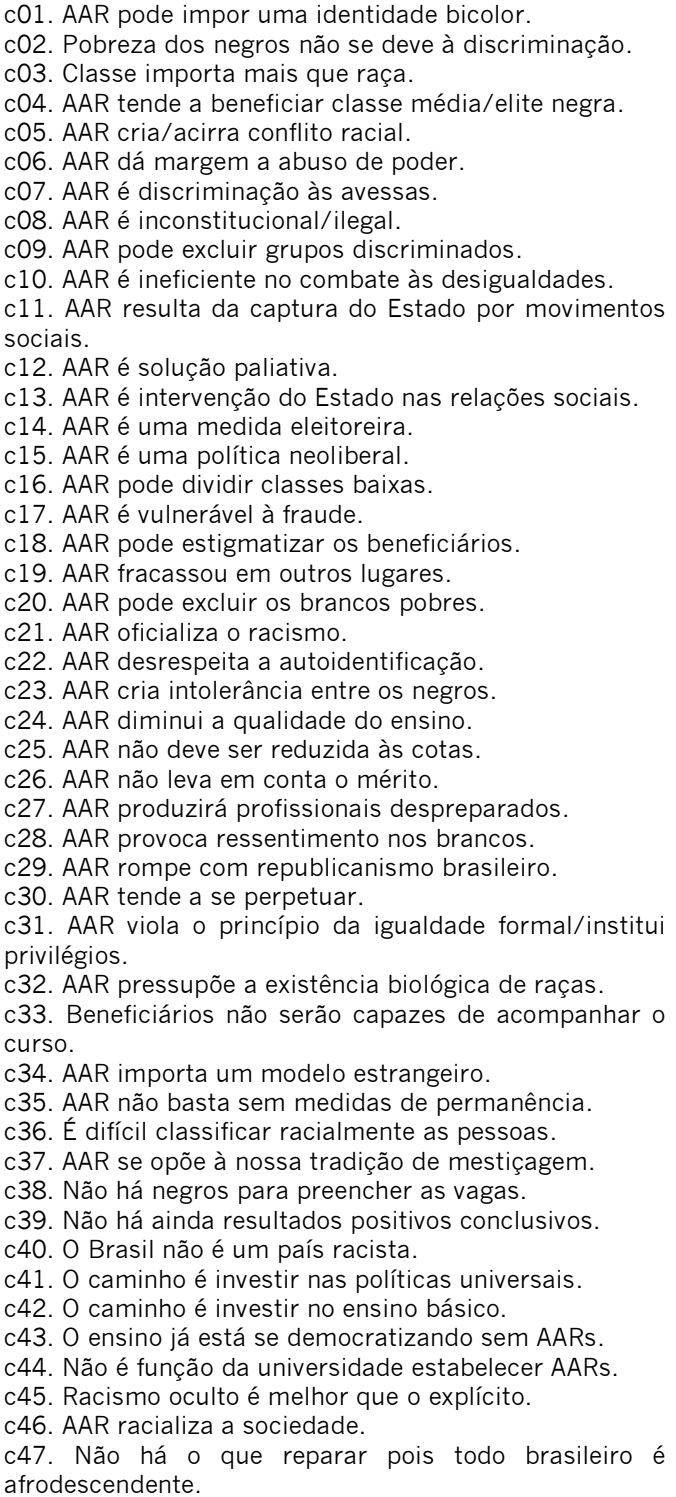 & $\begin{array}{l}\text { f01. AAR diminui as desigualdades (genérico). } \\
\text { fO2. AAR efetiva princípios constitucionais. } \\
\text { fO3. AAR realiza o princípio igualdade formal de tratamento. } \\
\text { fO4. AAR introduz os beneficiários na cidadania. } \\
\text { f05. AAR consolida/realiza princípios republicanos. } \\
\text { f06. AAR diminui as desigualdades (específico) } \\
\text { fO7. AAR inclui os excluídos (genérico). } \\
\text { fO8. AAR diminui as desigualdades socioeconômicas. } \\
\text { f09. AAR instaura a igualdade de oportunidades. } \\
\text { f10. AAR promove a mobilidade social de grupos discriminados. } \\
\text { f11. AAR capacitará os beneficiários a competir em igualdade. } \\
\text { f12. AAR tem estimulado o debate sobre as desigualdades } \\
\text { raciais. } \\
\text { f13. AAR dissocia cor de pobreza. } \\
\text { f14. AAR combate o racismo/discriminação (genérico). } \\
\text { f15. AAR combate } \quad \text { racismo/discriminação } \\
\text { institucional/estrutural. } \\
\text { f16. AAR combate o racismo/discriminação nas relações } \\
\text { sociais. } \\
\text { f17. AAR reconhece/denuncia o preconceito até então } \\
\text { encoberto. } \\
\text { f18. AAR cria uma classe média negra. } \\
\text { f19. AAR inclui os beneficiários nos níveis mais altos da } \\
\text { sociedade. } \\
\text { f20. AAR produz prosperidade/eficiência econômica. } \\
\text { f21. AAR inclui potenciais antes desperdiçados. } \\
\text { f22. AAR realiza o mérito. } \\
\text { f23. AAR repara erros cometidos no passado (genérico). } \\
\text { f24. AAR é uma forma de indenização aos que foram } \\
\text { escravizados. } \\
\text { f25. AAR busca dirimir os efeitos da escravidão no presente. } \\
\text { f26. AAR reconhece a diversidade cultural brasileira (genérico). } \\
\text { f27. AAR aumentará a autoestima dos beneficiários. } \\
\text { f28. AAR introduz pluralidade nas instituições. } \\
\text { f29. AAR reconhece contribuição histórico-cultural de } \\
\text { marginalizados. } \\
\text { f30. AAR realiza um projeto de nação. } \\
\text { f31. AAR é decisiva para a integração nacional. } \\
\text { f32. AAR é medida emergencial diante de uma situação crítica. } \\
\text { f33. AAR teve êxito em outros lugares. } \\
\text { f34. Há sinais de sucesso da AAR no Brasil. }\end{array}$ \\
\hline
\end{tabular}

Fonte: Gemaa.

\section{Mensurando as coocorrências através da Análise de Correspondências}

Tomando por base a lista de argumentos presentes no Quadro 1, já seria possível agrupá-los por semelhança e diferença em enquadramentos semanticamente homogêneos. Contudo, não é forçoso que as categorias semanticamente próximas componham um mesmo quadro interpretativo. Um enquadramento interpretativo pode articular conteúdos diferentes ou mesmo contraditórios em uma mesma linha argumentativa coerente. Ignorar esse fato é uma das principais deficiências dos estudos de 
CAMPOS, L. A. A identificação de enquadramentos através da análise de...

enquadramento, os quais optam por categorizar quadros interpretativos a partir das semelhanças entre um conjunto de elementos de assinatura sem, porém, verificar se tais elementos semelhantes de fato coocorrem nos textos de um dado corpus.

Uma forma de delinear o modo como tais elementos de assinatura são articulados em enquadramentos maiores pelos textos publicados na imprensa é medir quais deles mais ocorrem conjuntamente. Ou seja, é de esperar que subenquadramentos que costumam ser mencionados juntos em uma mesma comunicação façam parte de um mesmo enquadramento interpretativo maior. Mas, embora esse parâmetro seja adotado por alguns autores, não é tão simples estabelecer a coocorrência de determinados subenquadramentos.

Rousiley Maia, por exemplo, tenta mensurar tais coocorrências quando discute os enquadramentos produzidos pelos mesmos jornais estudados aqui sobre duas importantes problemáticas públicas: uma sobre a lei que propunha limitar a publicidade de cigarros em 2000 e o debate em torno do referendo sobre a comercialização de armas de fogo e munições, que ocorreu em 2005 (MAIA, 2009). Inspirada nos trabalhos de Chong e Druckman (2007), Maia mede a "copresença" de argumentos em torno das duas temáticas a partir da presença/ausência deles nos dois "lados" envolvidos nos debates estudados.

Contudo, a autora ignora que dificilmente os dois debates estudados podem ser reduzidos a dois "lados" homogêneos. Ao lidar com controvérsias em torno de propostas concretas, é sempre possível dividir os textos analisados em contrários e favoráveis às medidas propostas. Entretanto, não se pode ignorar a polifonia interna a cada um desses lados. Além disso, Maia apenas indica quais argumentos coocorrem em cada momento dos debates, deixando de considerar a intensidade com que eles coocorrem. Finalmente, não é forçoso que cada envolvido nos debates analisados por Maia mescle os mesmos argumentos citados pelo seu respectivo "lado" no debate. É possível supor que cada tomada de posição articule argumentos de uma forma particular, formando o seu próprio enquadramento dos temas estudados.

Um modo tradicional de medir graus de coocorrência que atenda a esses dois critérios é produzir tabelas de contingência em que os argumentos codificados para uma problemática são cruzados com eles mesmos. Desconsiderando que cada argumento costuma ocorrer mais com ele próprio, seria possível observar a partir desse cruzamento quais argumentos acompanham outros com mais frequência. Mas, no presente caso, isso significaria produzir uma tabela cruzada com cerca de 80 linhas e 80 colunas, ou seja, uma tabela com 6.400 células. Além de ser de difícil análise, essa tabela apenas apresentaria pares de coocorrências, não mostrando, assim, quando mais de dois argumentos coocorrem simultaneamente.

Uma forma de contornar essa limitação é recorrer à técnica de Análise de Correspondências Simples (ACS). A ACS é um recurso para expor em um mapa bidimensional as coocorrências relativas entre as classes de duas variáveis categóricas. A partir de uma tabela de contingência simples, em que duas variáveis são cruzadas, a ACS produz uma ilustração cartográfica das relações existentes entre todas as categorias incluídas. As categorias que mais coocorrem em termos relativos tendem a ser representadas mais próximas e, analogamente, as categorias com menor grau de coocorrência são representadas com uma distância maior entre si. Para definir a magnitude dessas distâncias relativas, a ACS considera as distâncias existentes entre os marginais observados na métrica do qui-quadrado. 
Desde os trabalhos pioneiros de Benzécri (1992) e Greenacre (1993) a ACS vem se tornando uma forma de expor uma grande multiplicidade de dados categóricos num mapa bidimensional de fácil interpretação. Notabilizada pela sociologia francesa a partir dos trabalhos de Pierre Bourdieu (2007), a ACS tem se demonstrado produtiva em tipos de pesquisas muito diferentes. Uma vez construída, a ACS pode ser analisada como um mapa cartográfico ou, para usar a metáfora de Bourdieu, como um campo magnético (BoURDIEU, 2007). Neste, os elementos que mais coocorrem tenderão a se atrair e, por isso, serão dispostos de forma próxima. Para entender os princípios utilizados na construção de uma ACS é útil recorrer a um exemplo fictício simples. Suponha-se que um pesquisador quer avaliar o grau de associação existente entre a satisfação de 86 consumidores e as marcas de televisão disponíveis no mercado. A Tabela 1 a seguir mostra as frequências observadas nessa investigação hipotética:

Tabela 1

Satisfação por marca de TV no exemplo hipotético

\begin{tabular}{|c|c|c|c|c|}
\hline & Satisfeito & Indiferente & Insatisfeito & Total \\
\hline Marca A & 6 & 1 & 11 & 18 \\
\hline Marca B & 1 & 3 & 11 & 15 \\
\hline Marca C & 4 & 25 & 0 & 29 \\
\hline Marca D & 2 & 2 & 20 & 24 \\
\hline Total & 13 & 31 & 42 & 86 \\
\hline
\end{tabular}

Esse cruzamento permite estabelecer, por exemplo, que a maior parte dos consumidores (42) selecionados não está satisfeita com as marcas incluídas na pesquisa e que a marca D é desaprovada por mais pessoas (20). Porém, para estabelecer a associação entre nível de satisfação e as marcas, é necessário considerar os pesos diferentes de cada categoria no universo. Ou seja, por mais que uma grande parcela dos grupos esteja insatisfeita com a marca D (20), é preciso considerar que os usuários dessa marca estão sobrerrepresentados. Uma forma de isolar o efeito dessa discrepância é considerar apenas os percentuais dos agregados de acordo com a satisfação em cada grupo. Todavia, isso ainda não permite julgar com precisão as melhores ou piores marcas em termos relativos, pois desconsidera que a maioria dos clientes está insatisfeita com suas televisões. O fato de um grupo preferir a televisão de uma dada marca, e estar, por isso, sobrerrepresentado no universo, talvez indique uma preferência racional pela melhor marca.

Uma forma de contornar esse problema é recorrer à padronização desses dados a partir das distâncias entre os dados observados e os dados esperados caso a distribuição da preferência pelas marcas de TV fosse uniforme. Ao lidar com dados categóricos, em geral existe uma expectativa implícita de que as distribuições sejam homogêneas. As análises estatísticas desse tipo buscam não somente estabelecer as frequências observadas numa dada população, mas também em que medida tais frequências se distanciam de uma distribuição homogênea.

No exemplo citado, seria esperado que o grau de satisfação com cada marca fosse proporcional à quantidade de usuários de cada marca e à quantidade de usuários satisfeitos, indiferentes e insatisfeitos respectivamente. Por isso, é possível obter essas frequências esperadas multiplicando a média percentual das linhas pelos subtotais observados nas colunas, ou multiplicando a média 
CAMPOS, L. A. A identificação de enquadramentos através da análise de...

percentual das colunas pelos subtotais observados nas linhas. A Tabela 2 reproduz as frequências "observadas" na pesquisa fictícia que usamos como exemplo e as frequências esperadas (entre parênteses) de acordo com o princípio de homogeneidade:

Tabela 2

Satisfação por marca de TV

(frequências observadas e esperadas)

\begin{tabular}{|c|c|c|c|c|c|}
\hline & Satisfeito & Indiferente & Insatisfeito & Total & Média \\
\hline Marca A & $\begin{array}{c}6 \\
(2,7)\end{array}$ & $\begin{array}{c}1 \\
(6,48)\end{array}$ & $\begin{array}{c}11 \\
(8,82)\end{array}$ & 18 & 0,21 \\
\hline Marca B & $\begin{array}{c}1 \\
(2,25)\end{array}$ & $\begin{array}{c}3 \\
(5,4)\end{array}$ & $\begin{array}{c}11 \\
(7,35)\end{array}$ & 15 & 0,17 \\
\hline Marca C & 4 & 0 & $(14,21)$ & 29 & 0,34 \\
\hline Marca D & $(4,35)$ & $(10,44)$ & $(11,76)$ & 24 & 0,28 \\
\hline Total & $(3,6)$ & $(8,64)$ & 42 & 86 &. \\
\hline Média & 13 & 31 & 0,49 & &. \\
\hline
\end{tabular}

O teste do qui-quadrado $\left(X^{2}\right)$ possibilita calcular a distância relativa entre as frequências observadas e aquelas esperadas. Calculando o qui-quadrado para o exemplo citado, chega-se ao resultado de 58,9. Trata-se de um valor elevado tomando como base o qui-quadrado tabelado para 6 graus de liberdade ${ }^{4}$, que é de 12,59 . Esse teste do qui-quadrado $\left(X^{2}\right)$ possibilita estabelecer em que medida cada categoria das linhas é independente das categorias das colunas, partindo da hipótese de homogeneidade. Entretanto, mais importante do que estabelecer o valor geral do qui-quadrado é notar que ele fornece a métrica para calcular as distâncias entre as frequências observadas e as esperadas. Uma vez efetuada essa uniformização dos dados, é possível representar as associações entre eles em um plano tridimensional, o qual, por seu turno, pode ser simplificado num plano bidimensional, conforme os Gráficos 1 e 2:

\footnotetext{
${ }^{4}$ Os graus de liberdade são calculados a partir da multiplicação entre o número de linhas menos 1 e o número de colunas menos 1 do cruzamento em questão: $g \mid=(\mid-1) \cdot(c-1)$.
} 
Gráfico 1

Grau de satisfação por marca da TV (mapa tridimensional)

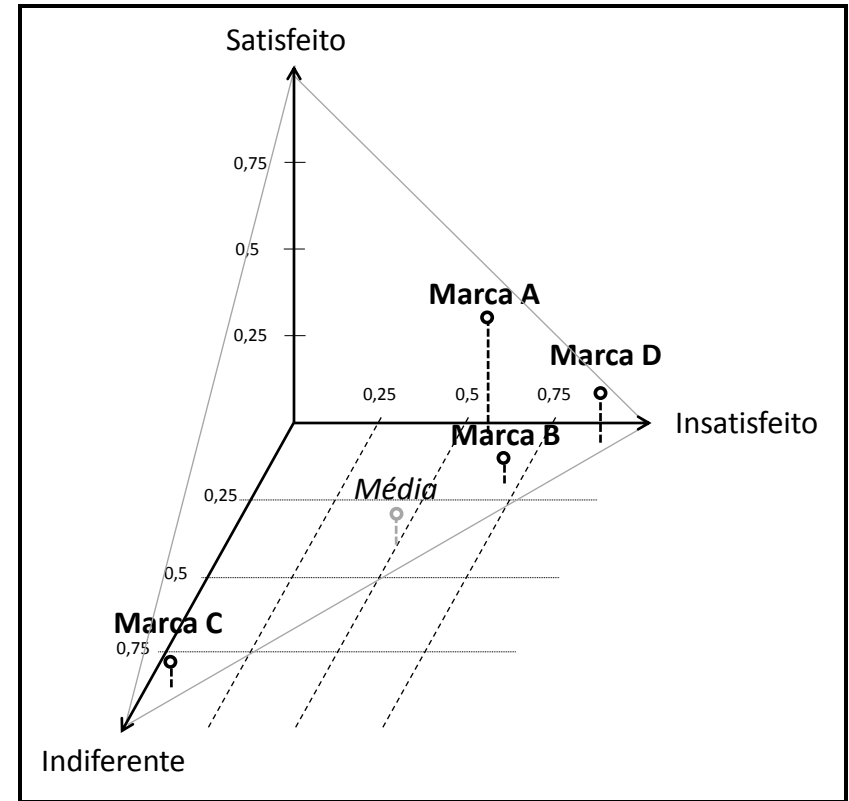

Fonte: Greenacre (1993) com modificações.

Gráfico 2

Grau de satisfação por marca da TV (mapa bidimensional)

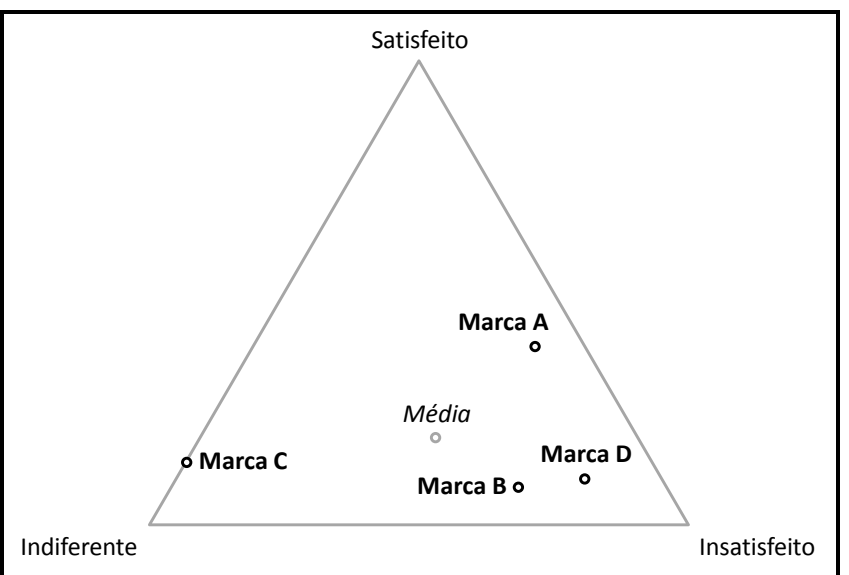

Fonte: Greenacre (1993) com modificações.

A Análise de Correspondências Simples segue todos esses passos para transformar um conjunto de dados categóricos relacionados em um mapa bidimensional em que podemos observar graficamente como as ocorrências entre dois conjuntos de categorias se associam. A seguir, apresentamos a ACS para o exemplo fictício discutido até aqui. 
CAMPOS, L. A. A identificação de enquadramentos através da análise de...

Gráfico 3

ACS para o grau de satisfação com as marcas de TV

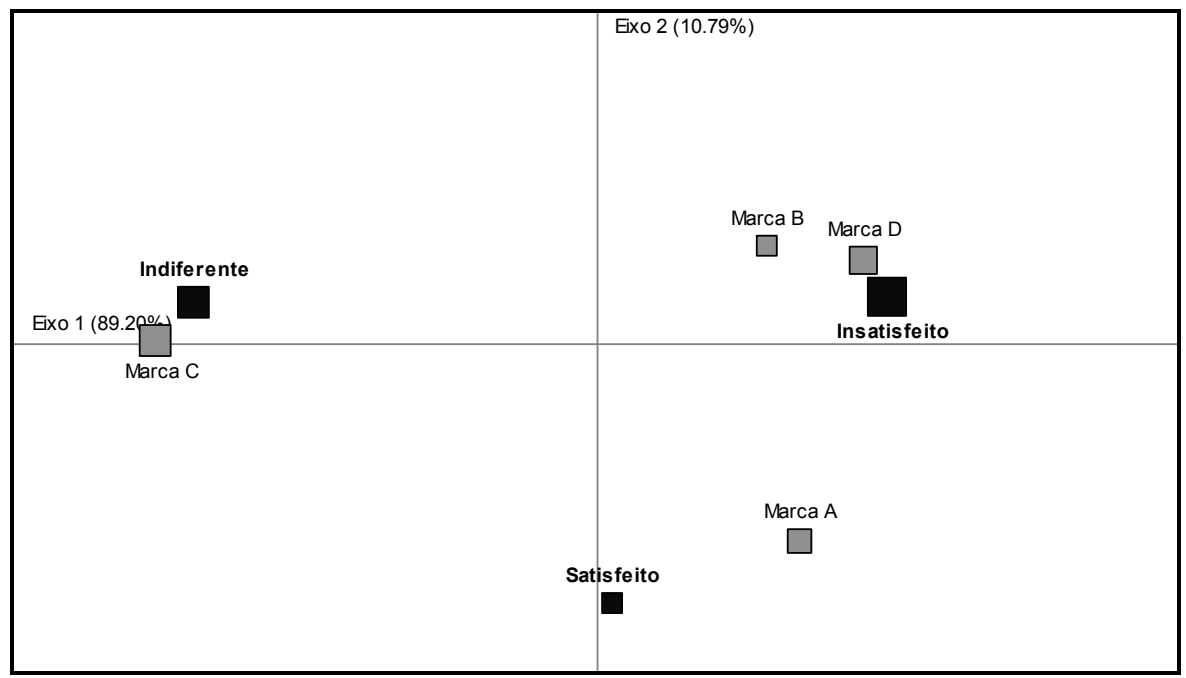

Fonte: Greenacre (1993) com modificações.

A partir dessa ACS, podemos perceber que a aparente vantagem da marca A não é tão grande, posto que, na métrica do qui-quadrado, ela possui um número considerável de insatisfeitos. Os números presentes em cada eixo dizem respeito ao percentual da variância indicada em cada eixo. No exemplo citado, $89,2 \%$ da variância é explicada pelo eixo horizontal. Ou seja, se o mapa fosse achatado verticalmente, resultando numa única linha horizontal, as distâncias latitudinais entre as categorias representariam $89,2 \%$ das correspondências existentes. Nesse caso, importa menos observar as distâncias na vertical. Isso indica que a associação entre as marcas e a satisfação dos clientes é mais ou menos linear, em que as marcas $B$ e $D$ induzem insatisfação, a marca $C$ induz indiferença, enquanto a marca A divide as opiniões entre satisfação e insatisfação. Contudo, nas análises que se seguem, a inércia dos eixos pode ser ignorada, já que não se trata de uma pesquisa feita por amostragem.

Mas a ACS apresenta limitações. Nem todo cruzamento entre duas variáveis categóricas apresenta graus de dependência relevantes no teste do qui-quadrado, o que torna a análise pouco elucidativa. Além disso, por se basear numa série de medidas relacionais, ela tende a sobrestimar pequenas distâncias absolutas, mas que apresentam grande peso relativo. Assim, se for observada frequência diminuta em alguma categoria ou se esta ocorrer pouco com as demais, tal categoria tenderá a repelir as demais para o centro do mapa, impedindo que eventuais relações sejam identificáveis. Nesse caso, tem-se uma ACS muito assimétrica, na qual a pouca coocorrência de uma categoria aumenta a inércia total de todo o mapa, fazendo com que as demais categorias se concentrem no centro do mapa.

Mas, do mesmo modo que num campo magnético, é possível remover os códigos com força desproporcional em relação aos demais de modo a melhor visualizar as relações estabelecidas entre os outros argumentos. A rigor, isso não implica remover tais argumentos do corpus como um todo, mas apenas fundi-los aos argumentos semanticamente mais próximos para melhor visualizar as correspondências. Assim, para obter mapas mais equilibrados, basta definir quais códigos se distanciam do centro do mapa para além de um patamar tolerável, ou seja, os outliers em termos de distâncias. Em 
seguida, esses outliers podem ser fundidos a outros códigos similares. Ademais, existe uma justificativa teórica para adotar tal procedimento. Pois, se tais outliers pouco aparecem no corpus, eles não devem influenciar tanto a representação da análise. Portanto, eliminá-los ou fundi-los - que é uma alternativa ainda mais vantajosa, pois diminui as perdas semânticas - é um procedimento que gera maior clareza.

Aglutinando elementos de assinatura

O Gráfico 4 apresenta a ACS dos argumentos detectados em todo o corpus. Nesse mapa, já é possível perceber algumas características da forma como o tema das ações afirmativas raciais no ensino superior é enquadrado nos dois jornais. Em primeiro lugar, vale notar que os argumentos contrários (códigos começados com a letra "c") se concentram no lado esquerdo do mapa, enquanto os argumentos favoráveis (indicados pela letra "f") aparecem mais dispersos no lado direito. Além disso, excetuando-se dois argumentos (c25 e c35), há uma nítida fronteira entre argumentos contrários e favoráveis. Isso indica que são raros os textos em que argumentos contrários aparecem citados juntos com argumentos favoráveis. Logo, o mapa de correspondências apresenta uma característica geral do enquadramento editorial produzido pelos dois jornais estudados, qual seja, a divisão da maior parte dos textos publicados sobre as ações afirmativas raciais em dois campos distintos: um favorável e outro contrário às políticas afirmativas.

Gráfico 4

ACS dos argumentos em relação às ações afirmativas raciais

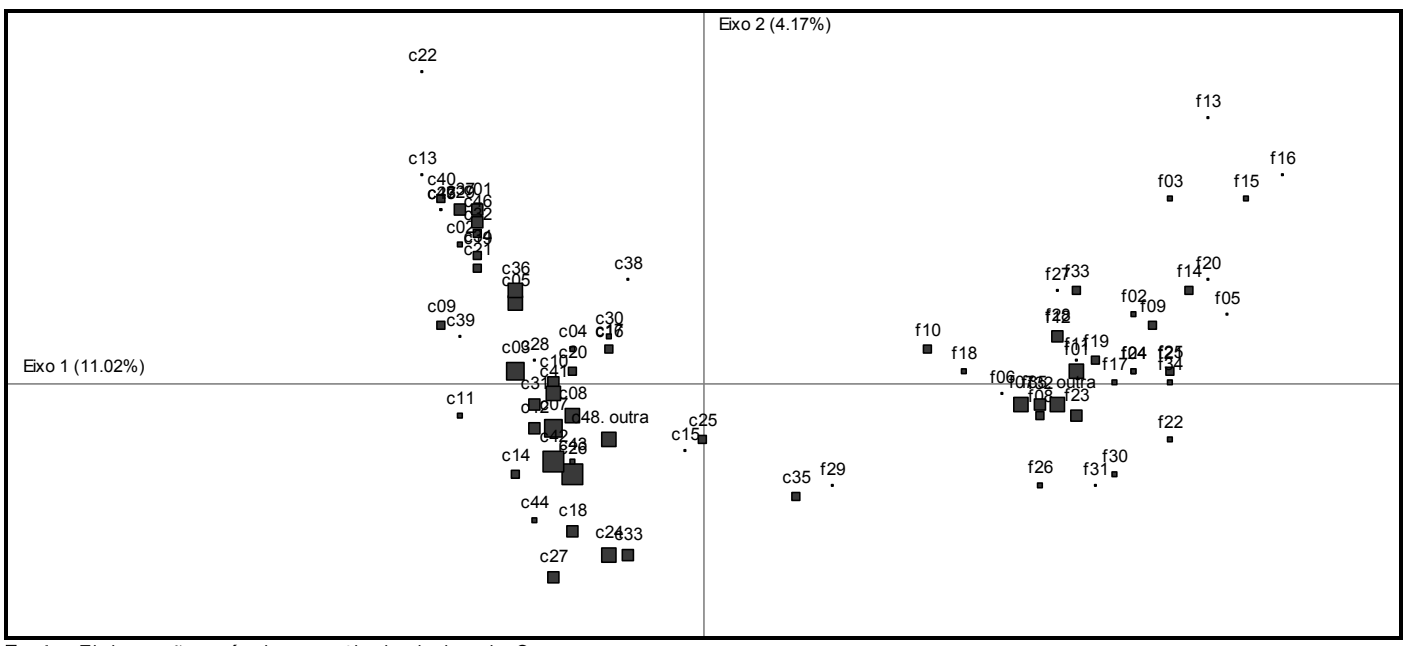

Fonte: Elaboração própria a partir de dados do Gemaa.

$\mathrm{N}=1.192$ textos

O fato de os argumentos contrários se concentrarem de um lado do mapa e os favoráveis de outro indica que poucos foram os textos que assumiram argumentos de ambos os tipos. Ao que parece, a construção do debate nos jornais privilegiou uma visão antagonista da questão ao separar em seus textos subenquadramentos contrários daqueles favoráveis. Todavia, essa ACS não leva em conta as particularidades próprias de cada um dos jornais incluídos no corpus. Porém, como é possível perceber no Gráfico 5 e no Gráfico 6, tanto O Globo quanto a Folha de S. Paulo respectivamente parecem organizar os argumentos de forma muito semelhante. Embora cada um dos periódicos apresente 
nuances, ambos lidaram com a temática como uma questão disruptiva e que suscita duas opiniões polares, uma contrária e outra favorável.

\section{Gráfico 5}

ACS dos argumentos presentes em $O$ Globo

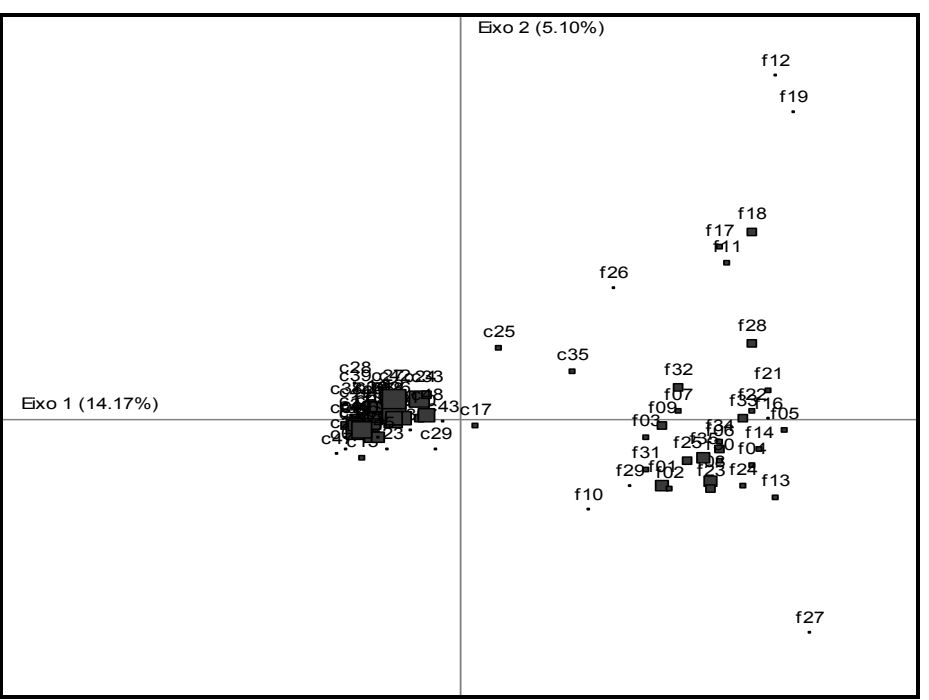

Fonte: Elaboração própria a partir de dados do Gemaa. $\mathrm{N}=682$ textos

\section{Gráfico 6}

ACS dos argumentos presentes na Folha de $S$. Paulo

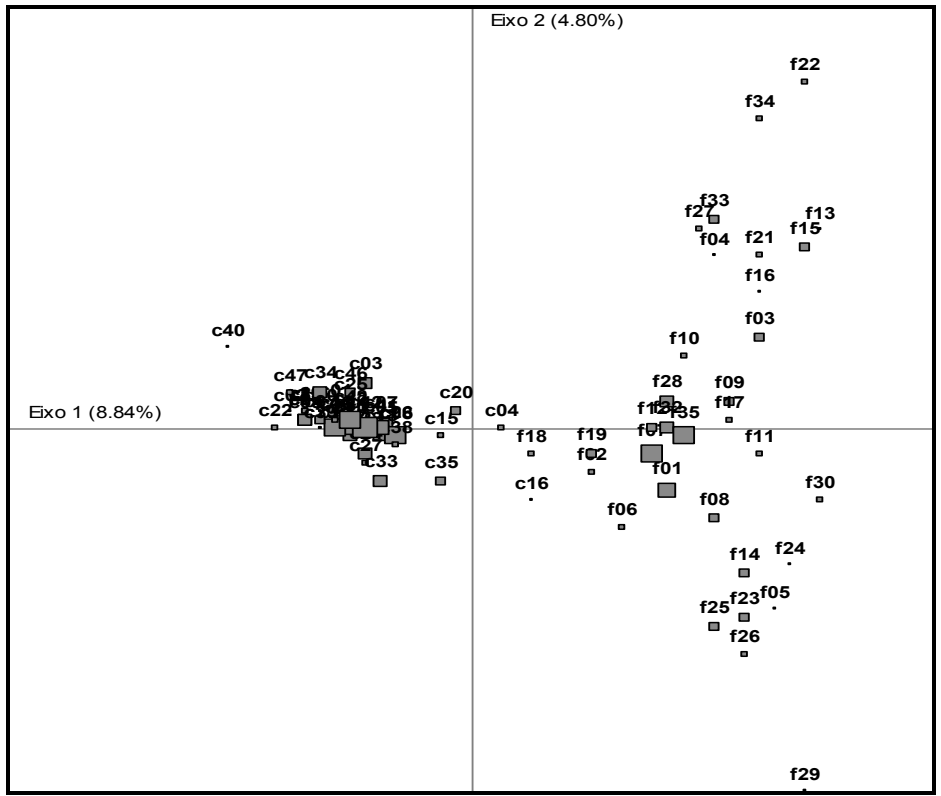

Fonte: Elaboração própria a partir de dados do Gemaa.

$\mathrm{N}=510$ textos 
À primeira vista, outro dado que chama a atenção nessas ACSs é o fato de a densidade dos argumentos contrários ser maior do que a dos favoráveis. Isso ocorre porque os argumentos contrários mais coocorrem em termos relativos do que os favoráveis. Outro elemento que chama atenção é a nítida separação entre argumentos contrários e favoráveis. Temos, assim, a primeira característica importante do modo como o tema das ações afirmativas raciais foi enquadrado por O Globo e Folha de S. Paulo. Ambos os jornais, de forma muito similar, apresentaram a política como uma controvérsia entre duas alas diametralmente opostas. Porém, essas ACSs são insensíveis às diferenças narrativas que particularizam os textos jornalísticos, mormente aquela que distingue a forma dos textos opinativos da dos textos noticiosos.

O advento do ideal da neutralidade jornalística reconfigurou não só as rotinas midiáticas, mas também a própria organização visual dos jornais impressos. Já em meados do século XX, os periódicos começam a adotar uma série de divisões internas, dentre as quais a mais importante é aquela que separa as notícias ditas informativas dos chamados artigos ou colunas de opinião. Tal divisão está calcada na ideia de que informação e opinião devem - e podem - ser distinguidas. Daí resultaria que o espaço dedicado à publicação de notícias deveria ser nitidamente distinguido do espaço dedicado à publicação dos textos opinativos.

No entanto, as seções opinativas dos jornais devem ser interpretadas não como espaços em que o ideal de imparcialidade jornalística é flexibilizado, mas sim como espaços em que esse ideal é reformulado. Nas seções opinativas, o jornal se apresenta como uma entidade imparcial, não por se ater estritamente aos fatos reportados, mas por ceder espaço às divergências supostamente constitutivas da esfera pública como um todo. Já nas reportagens, o ideal da imparcialidade jornalística seria supostamente realizado pela incidência de procedimentos profissionais, próprios da prática jornalística, os quais garantiriam uma representação mais ou menos fidedigna de uma dada realidade. Nas matérias jornalísticas, o ideal da imparcialidade se realizaria a partir de um respeito ao valor da objetividade, enquanto nas seções opinativas o jornal realizaria o ideal da imparcialidade ao respeitar o valor da pluralidade axiológica.

Baseado nisso, o Gráfico 7 apresenta a ACS dos elementos de assinatura codificados nos textos opinativos, enquanto o Gráfico 8 apresenta a ACS dos argumentos mencionados pelas reportagens. Enquanto nos dois gráficos a posição dos códigos permanece constante (códigos contrários à esquerda, favoráveis à direita), no mapa gerado para as reportagens o fosso que separa as duas alas argumentativas diminui consideravelmente. 
CAMPOS, L. A. A identificação de enquadramentos através da análise de...

Gráfico 7

ACS dos argumentos presentes em textos opinativos

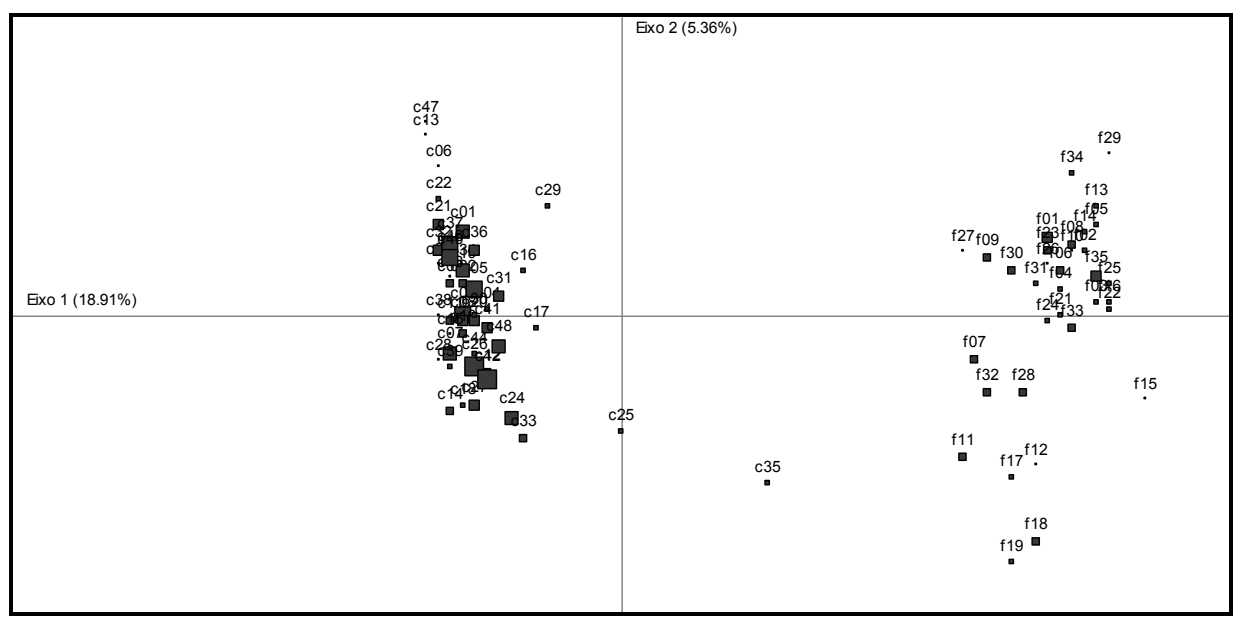

Fonte: Elaboração própria a partir de dados do Gemaa.

$\mathrm{N}=791$ textos.

\section{Gráfico 8}

ACS dos argumentos presentes nas reportagens

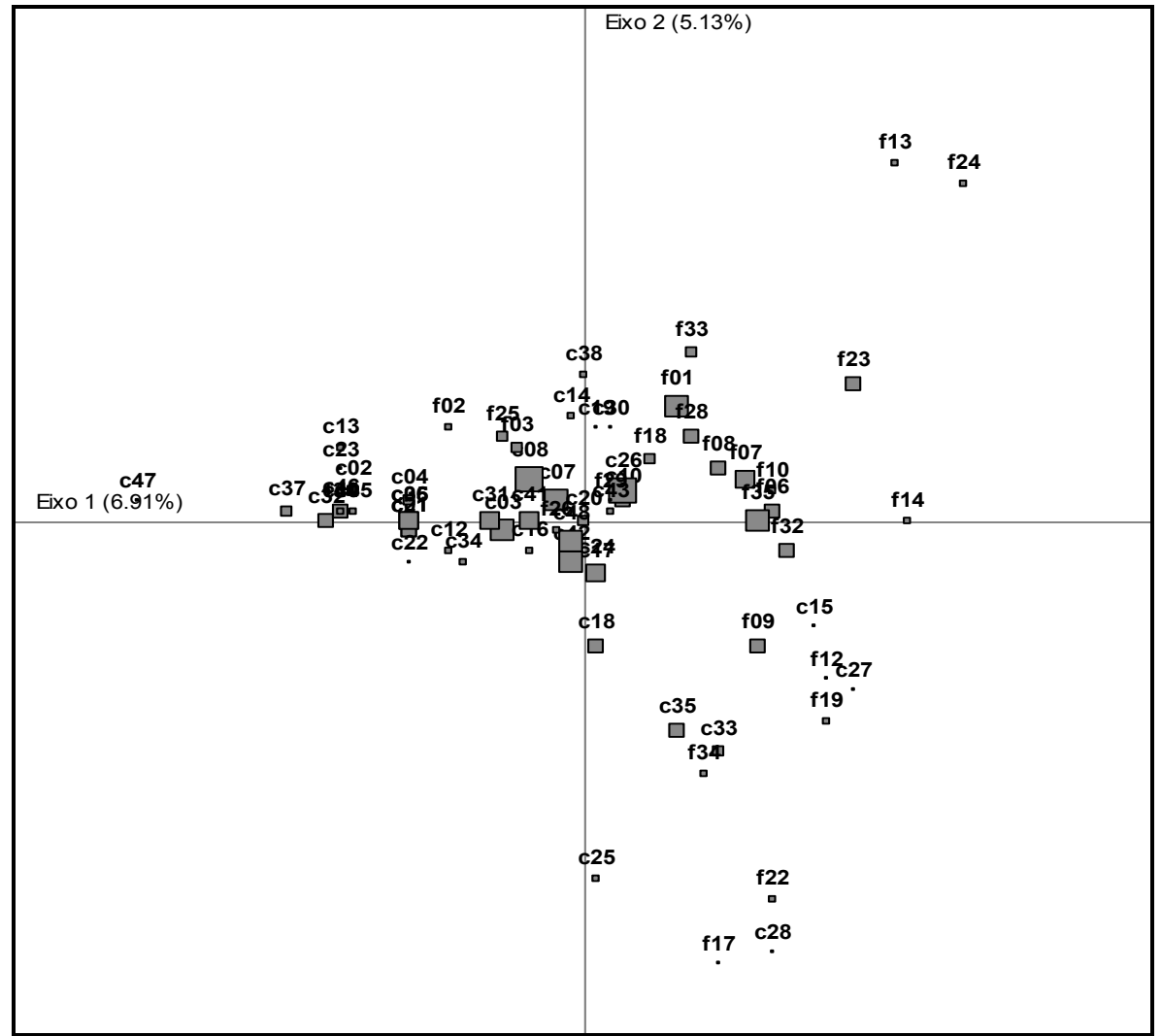

Fonte: Elaboração própria a partir de dados do Gemaa.

$\mathrm{N}=401$ textos. 
Comparando esses dois gráficos, é possível atestar a diferença no modo como os subenquadramentos são organizados em textos opinativos, de um lado, e em reportagens, do outro. Textos opinativos costumam articular em uma mesma argumentação subenquadramentos coerentes com uma mesma tomada de posição em relação às ações afirmativas raciais, enquanto as notícias são compostas narrativamente levando em conta subenquadramentos concorrentes. Tomados individualmente, cada texto opinativo representa uma dada posição no debate, mas, no atacado, eles conformam uma imagem bipartite do debate em torno das ações afirmativas raciais. As reportagens, por seu turno, internalizam no texto esse mesmo princípio de divisão dos argumentos. Noutros termos, as tomadas de posição divididas em diferentes textos opinativos são congregadas em notícias. Mas, embora o fosso diminua, os argumentos contrários permanecem de um lado oposto aos favoráveis. Embora nossa pesquisa não tenha levado em conta outros elementos da disposição dos textos nas páginas dos jornais, como o destaque maior ou menor a um texto de acordo com sua valência, isso indica que reportagens continuam dando maior espaço a um dos lados do debate, ainda que tal tendência seja mais matizada em comparação ao que ocorre nos textos opinativos.

Tão importante quanto estabelecer como determinados argumentos são articulados em uma dada cobertura midiática é definir de que modo eles são organizados no interior de cada texto. As ACSs supracitadas permitem perceber que, no geral, os argumentos foram organizados em "alas" distintas e que tais fronts se distanciam ou se aproximam dependendo da seção editorial considerada (de opiniões ou de reportagens). Porém, essas ACSs impedem que percebamos as características semânticas de cada um desses lados da polêmica em separado. Para tal, é necessário considerar como os argumentos contrários interagem com eles próprios e verificar o mesmo com os argumentos favoráveis. Vejamos, primeiramente, como se comporta a ACS no caso dos argumentos contrários:

\section{Gráfico 9}

ACS dos argumentos contrários

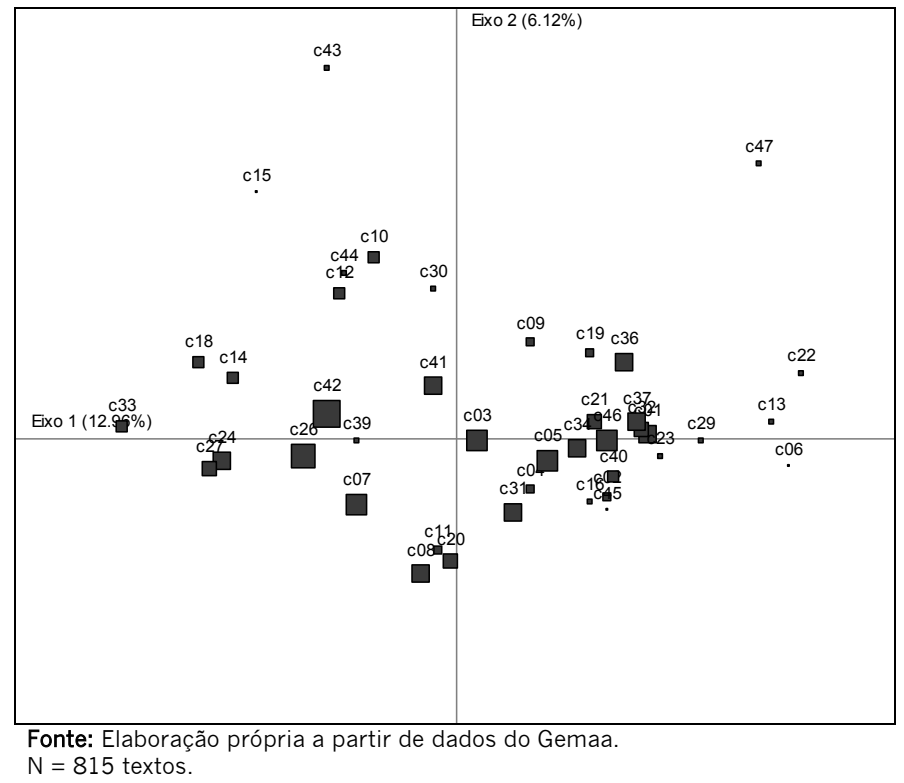


CAMPOS, L. A. A identificação de enquadramentos através da análise de...

É possível perceber no Gráfico 9 que os argumentos que aparecem próximos ao centro do eixo vertical e levemente deslocados à direita no eixo horizontal apresentam uma continuidade semântica e simultaneamente uma grande correspondência entre si. São eles os argumentos c01 (AAR pode impor uma identidade bicolor), c05 (AAR cria/acirra conflito racial), c16 (AAR pode dividir classes baixas), c21 (AAR oficializa o racismo), c32 (AAR pressupõe a existência biológica de raças), c34 (AAR importa um modelo estrangeiro), c36 (É difícil classificar racialmente as pessoas), c40 (O Brasil não é um país racista), c37 (AAR se opõe à nossa tradição de mestiçagem), c45 (Racismo oculto é melhor que explícito), c46 (AAR racializa a sociedade) etc.

Em conjunto, esses argumentos apontam para o potencial disruptivo das ações afirmativas baseadas na raça, seja porque a ideia de raça contrasta com a tradição cultural nacional, seja porque ela é em si nociva. Noutros termos, todos esses argumentos propugnam que as ações afirmativas raciais lidam de forma controversa com a ideia de raça, o que pode fazer com que a política introduza no país conflitos e polaridades identitárias nefastas. $\mathrm{E}$ o fato de que estão em uma região contígua do mapa não indica apenas que esses argumentos são similares, mas sim que eles costumam aparecer juntos no interior dos textos incluídos no corpus.

Analogamente, os códigos c24 (AAR diminui a qualidade do ensino), c26 (AAR não leva em conta o mérito), c27 (AAR produzirá profissionais despreparados), c33 (Beneficiários não serão capazes de acompanhar o curso) e c42 ( 0 caminho é investir no ensino básico) se concentram no meio do eixo vertical e bem à esquerda do eixo horizontal, formando outro cluster de argumentos que costumam ocorrer juntos na cobertura midiática. Pelos rótulos, é possível perceber que tais argumentos têm em comum o fato de sublinharem os possíveis malefícios que a ação afirmativa racial pode gerar na educação ao flexibilizar os critérios de admissão, piorando a qualidade dos alunos que entram e saem das universidades, do ensino como um todo e, também, por colocar em um segundo plano os investimentos prioritários no ensino básico.

Na parte inferior central do Gráfico 11, com os argumentos que apontam para a possibilidade de racialização e os argumentos centrados nos perigos à educação, há uma diversidade menos nítida de argumentos. De um lado, os argumentos c07 (AAR é discriminação às avessas), c08 (AAR é inconstitucional/ilegal), c11 (AAR resulta da captura do Estado por movimentos sociais), c26 (AAR não leva em conta o mérito), c31 (AAR viola o princípio da igualdade formal/institui privilégios) e c41 ( 0 caminho é investir nas políticas universais) colocam questões relativas ao respeito ao Estado de direito e à cidadania. Nesse enquadramento, a imparcialidade jurídica seria violentada pela ação afirmativa, pois esta criaria privilégios. Logo, a medida seria uma forma de discriminação às avessas que não respeita o princípio universalista do mérito.

Do outro lado, os subenquadramentos como c02 (Pobreza dos negros não se deve à discriminação), c03 (Classe importa mais que raça) e c20 (AAR pode excluir os brancos pobres) apontam para a prioridade das desigualdades socioeconômicas sobre as desigualdades raciais. Dessa perspectiva, não caberia implantar ações afirmativas de corte racial em um contexto em que as desigualdades são na verdade socioeconômicas. Existiria apenas uma infeliz coincidência, historicamente construída, entre negritude e pobreza, mas esta poderia ser matizada com políticas universalistas de redistribuição.

Uma nuvem maior de argumentos que coocorrem pode ser detectada em toda a parte superior do mapa, delineada pelos códigos c42 (O caminho é investir no ensino básico), c14 (AAR é uma medida 
eleitoreira), c18 (AAR pode estigmatizar os beneficiários), c44 (Não é função da universidade estabelecer AARs), c30 (AAR tende a se perpetuar), c09 (AAR pode excluir grupos discriminados), c19 (AAR fracassou em outros lugares), c04 (AAR tende a beneficiar classe média/elite negra) e c41 (O caminho é investir nas políticas universais), que também engloba os argumentos c10 (AAR é ineficiente no combate às desigualdades) e c12 (AAR é solução paliativa). A despeito da multiplicidade, esses argumentos sugerem que a ação afirmativa racial terá muitos efeitos reversos ou que, na verdade, existem alternativas menos perigosas para solucionar os problemas que ela pretende remediar. Trata-se, assim, de uma medida que representa interesses equivocados, ineficiente em seus meios e defendida com fins eleitorais. Diante disso, o Gráfico 10 localiza a partir de marcações coloridas cada um dos agrupamentos detectados nos parágrafos anteriores.

\section{Gráfico 10}

ACS dos argumentos contrários marcados por cores de acordo com similaridade e contiguidade dos códigos

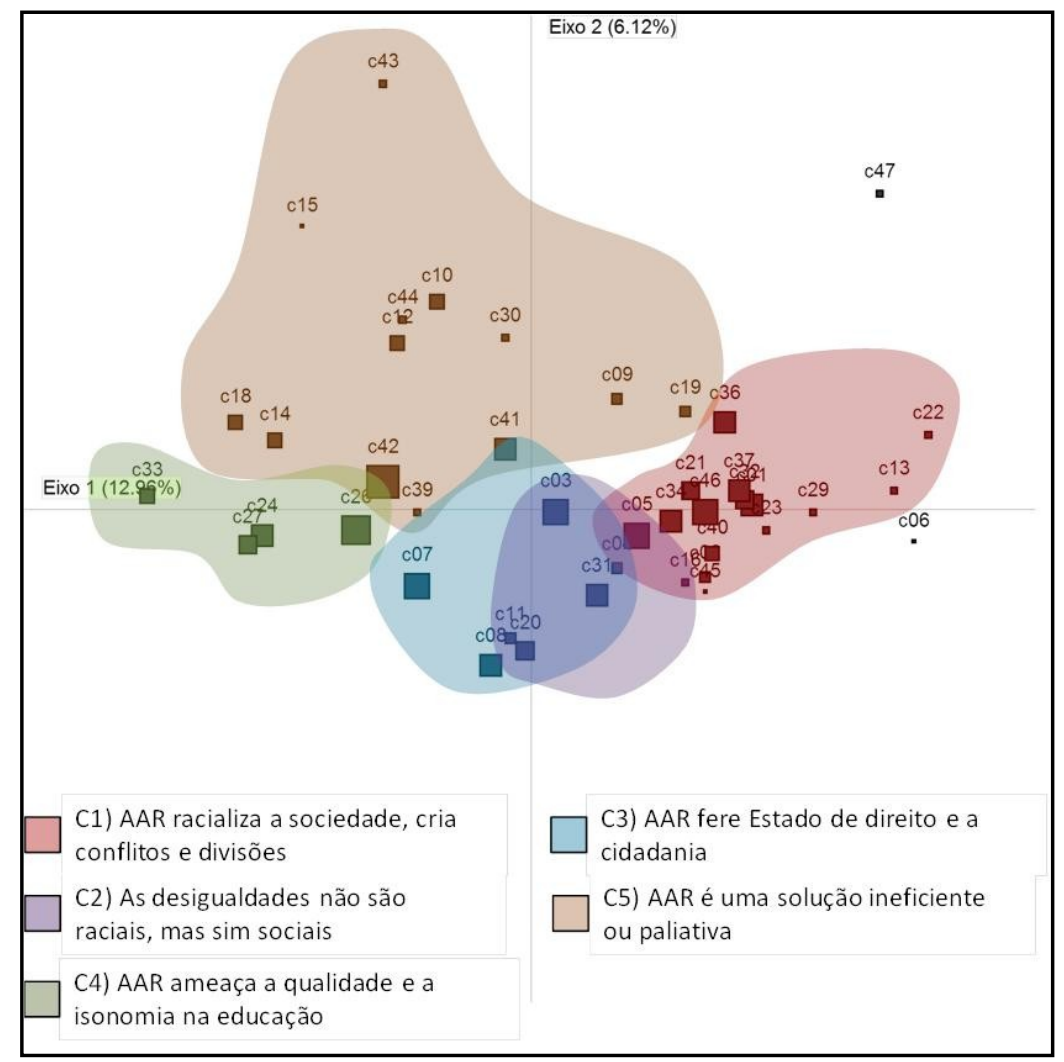

Fonte: Elaboração própria a partir de dados do Gemaa.

$\mathrm{N}=815$ textos.

Essas cinco nuvens podem ser tomadas como os cinco principais enquadramentos interpretativos contrários às ações afirmativas raciais, articulados nos dois jornais. A ACS possibilitou que a formalização se desse com base em critérios interpretativos, como a contiguidade semântica entre 
CAMPOS, L. A. A identificação de enquadramentos através da análise de...

os argumentos, e também em critérios indutivos baseados no modo como eles são combinados nos textos. Na legenda do Gráfico 10, está a lista dos cinco enquadramentos interpretativos contrários, formalizados a partir da ACS e indicados pela letra "C" maiúscula (diferenciando-se dos argumentos indicados pela letra "c" minúscula).

Além de viabilizar a validação de uma dada tipologia de enquadramentos interpretativos, a ACS exposta no Gráfico 10 permite delinear algumas características gerais deles. Primeiro, os quatro enquadramentos que se situam na base do gráfico possuem correspondências com os argumentos focados na ineficiência das ações afirmativas raciais (C5). Isso quer dizer que a ineficiência dessas políticas é um argumento compartilhado por quase todos que atacam as ações afirmativas raciais. Por outro lado, não há interseção entre os argumentos que apontam para os supostos efeitos negativos da política na educação (C4) e aqueles centrados na ideia de racialização (C1). Isso indica que os textos que destacam a possibilidade de racializar a sociedade ou criar conflitos raciais a partir da difusão de ações afirmativas raramente compartilham a opinião de que a política colocará em perigo a qualidade do ensino. Finalmente, há uma quase perfeita sobreposição entre os argumentos que defendem o caráter socioeconômico das desigualdades (C3) e aqueles que atacam as ações afirmativas raciais como medidas ilegais ou inconstitucionais (C2).

Da mesma forma que o Gráfico 9 apresenta as relações entre os argumentos contrários às ações afirmativas raciais, o Gráfico 11 apresenta a ACS construída para os argumentos favoráveis:

Gráfico 11

ACS dos argumentos favoráveis

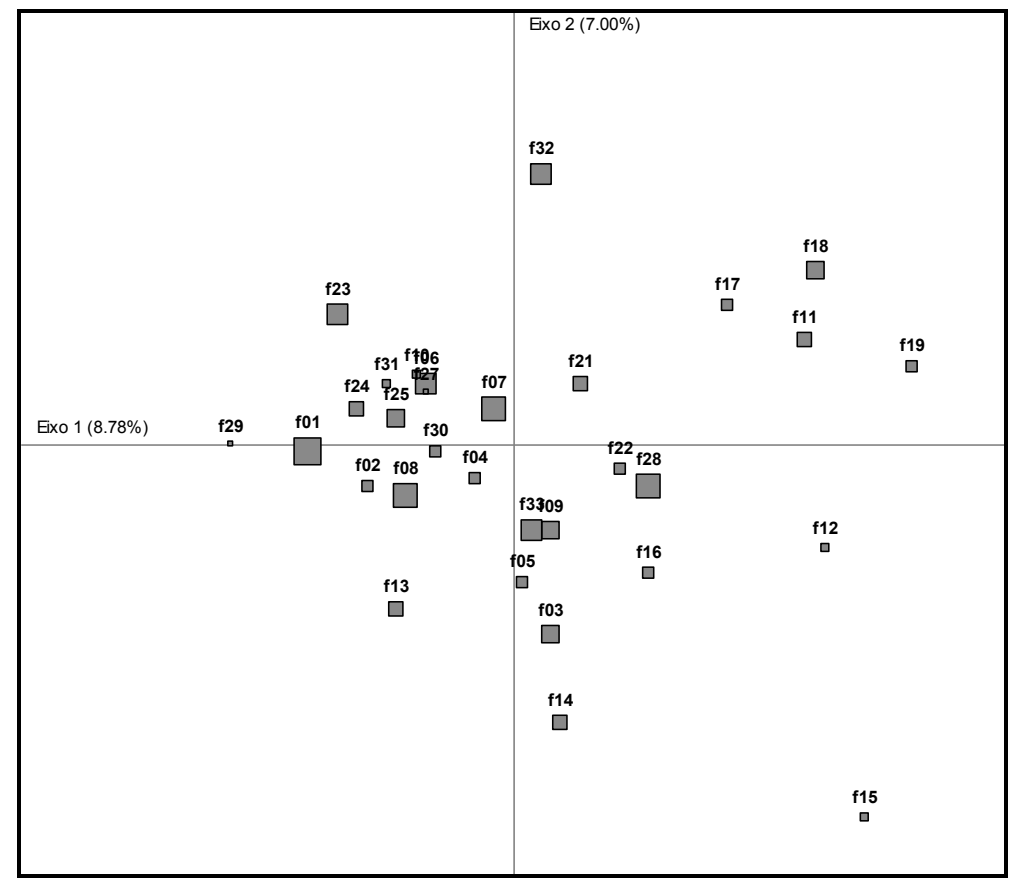

Fonte: Elaboração própria a partir de dados do Gemaa. $\mathrm{N}=552$ textos. 
À exceção de alguns argumentos, a maioria dos códigos no Gráfico 11 se distribui de forma muito mais simétrica que na ACS dos argumentos contrários (Gráfico 9). O fato de não existirem agrupamentos nítidos de códigos não quer dizer que a coocorrência entre eles seja baixa, mas sim que nenhum grupo de argumentos aparece junto mais que a média geral de coocorrências. A distância gráfica de alguns argumentos semanticamente próximos, por seu turno, é um indício de que cada texto costuma mesclar argumentos de significados diferentes em vez de priorizar uma linha argumentativa determinada, tendência muito distinta daquela presente nas tomadas de posição contrárias às políticas de discriminação positiva.

Ainda assim, é possível identificar algumas continuidades entre códigos semelhantes. No quadrante inferior direito do mapa, é possível notar uma semelhança geral entre os argumentos f03 (AAR realiza o princípio igualdade formal de tratamento), f02 (AAR efetiva princípios constitucionais), f05 (AAR consolida/realiza princípios republicanos), f09 (AAR instaura a igualdade de oportunidades), f14 (AAR combate o racismo/discriminação - genérico), f15 (AAR combate o racismo/discriminação institucional/estrutural), f16 (AAR combate o racismo/discriminação nas relações sociais) e f22 (AAR realiza o mérito). Esses sete argumentos defendem as ações afirmativas raciais como forma de efetivar a igualdade de tratamento, atacando assim a discriminação racial. Não obstante partidários de diferentes ideários remetam a esse enquadramento, vale a pena atentar para o modo como ele expressa os valores próprios de uma tradição liberal que vê na igualdade de oportunidades e de tratamento a base de uma sociedade justa. Ao se referir a esse argumento, não se está defendendo necessariamente uma sociedade com pouca desigualdade entre as classes, mas sim uma sociedade que ofereça a todos as mesmas oportunidades de ascensão.

Do lado esquerdo do mapa, é possível identificar subenquadramentos de duas naturezas. De um lado, estão os códigos f01 (AAR diminui as desigualdades - genérico), f04 (AAR introduz os beneficiários na cidadania), f07 (AAR inclui os excluídos - genérico), f08 (AAR diminui as desigualdades socioeconômicas), f10 (AAR promove a mobilidade social de grupos discriminados) e f13 (AAR dissocia cor de pobreza). Em conjunto, esses argumentos compõem um discurso que afirma que ação afirmativa racial diminui as desigualdades sociais e inclui os excluídos na cidadania ao promover a mobilidade social dos beneficiários. A ênfase nesse agrupamento argumentativo é na redistribuição de recursos e não somente na redistribuição de oportunidades sociais. A rigor, ambas as linhas argumentativas costumam vir juntas, mas, como há momentos em que as ênfases particularizam a argumentação, faz-se necessário distingui-las em dois enquadramentos.

À extrema esquerda do Gráfico 11 é possível perceber uma série de argumentos mais comunitaristas, que enfatizam o fato de a ação afirmativa racial reparar os efeitos nocivos da escravidão, aumentando a autoestima dos negros, reconhecendo a contribuição histórico-cultural deles e, assim, integrando-os à nação. Sob essa rubrica estão os subenquadramentos f23 (AAR repara erros cometidos no passado - genérico), f24 (AAR é uma forma de indenização aos que foram escravizados), f25 (AAR busca dirimir os efeitos da escravidão no presente), f27 (AAR aumentará a autoestima dos beneficiários), f29 (AAR reconhece contribuição histórico-cultural de marginalizados), f30 (AAR realiza um projeto de nação) e f31 (AAR é decisiva para a integração nacional).

Já a nuvem que abrange os subenquadramentos f11 (AAR capacitará os beneficiários a competir em igualdade), f18 (AAR cria uma classe média negra), f19 (AAR inclui os beneficiários nos 
CAMPOS, L. A. A identificação de enquadramentos através da análise de...

níveis mais altos da sociedade), f21 (AAR inclui potenciais antes desperdiçados) e f28 (AAR introduz pluralidade nas instituições) congrega os argumentos que acreditam que as ações afirmativas aumentam a competitividade dos grupos beneficiados, possibilitando que eles acessem posições de elite até então fechadas. Esses argumentos são diferentes versões da alcunhada teoria do creamy layer, isto é, a ideia de que as ações afirmativas ajudam a formar uma "nata", uma elite negra.

Os argumentos f32 (AAR é medida emergencial diante de uma situação crítica), f33 (AAR teve êxito em outros lugares) e f34 (Há sinais de sucesso da AAR no Brasil) não formam uma nuvem, mas podem ser agrupados em um mesmo cluster. Isso porque esses argumentos não são justificações propriamente ditas, mas recursos argumentativos que buscam embasar uma tomada de posição a partir de uma postura pragmática. Assim como no caso dos enquadramentos contrários, as áreas de contiguidade semântica que indicam os enquadramentos favoráveis aparecem em cores distintas no Gráfico 12:

\section{Gráfico 12}

ACS dos argumentos favoráveis marcados por cores de acordo com contiguidade e similaridade dos códigos

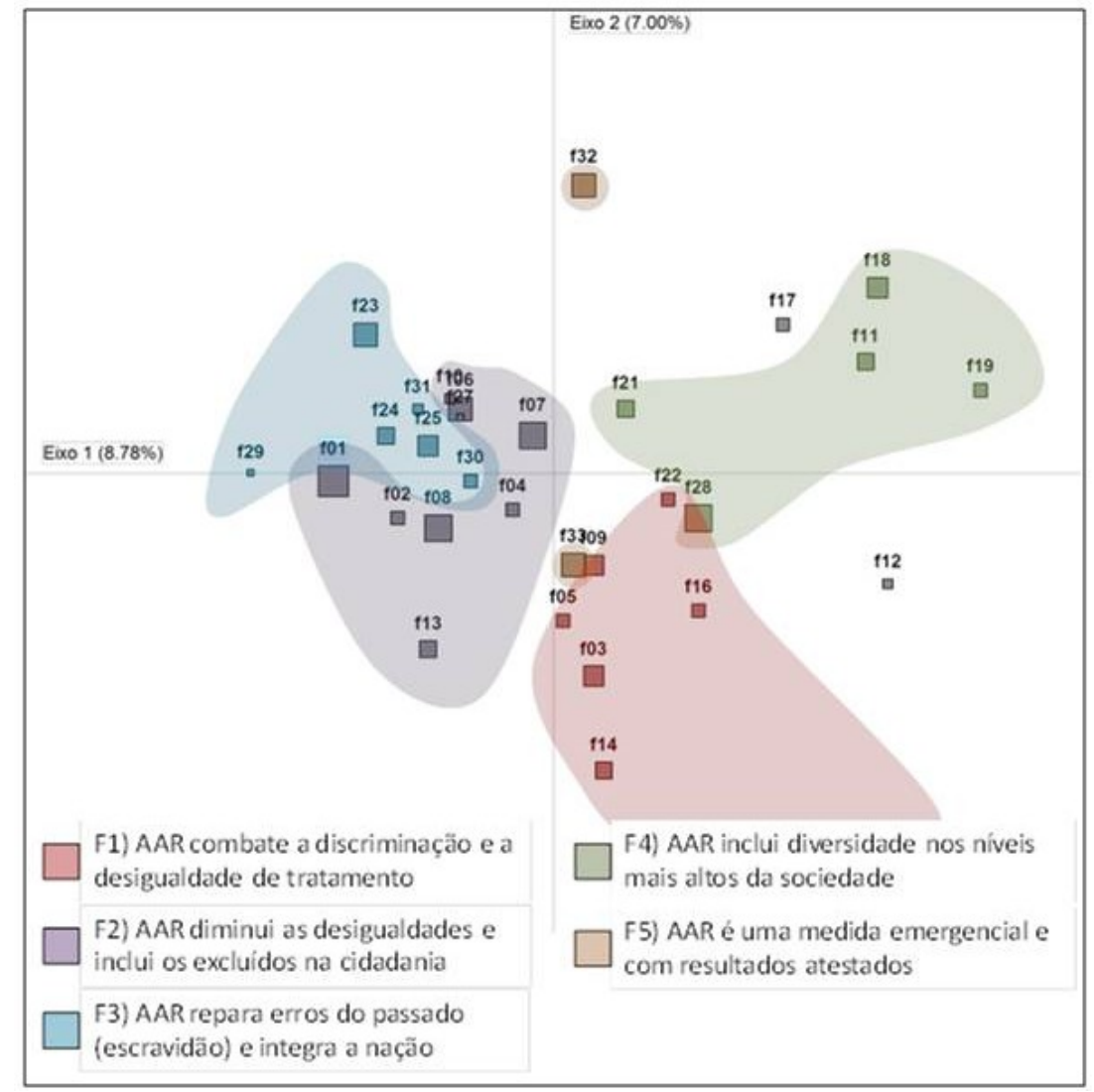

Fonte: Elaboração própria a partir de dados do Gemaa. $\mathrm{N}=552$ textos. 
Novamente, o mapa de correspondências apresentado permite delinear algumas conclusões preliminares sobre o modo como os argumentos favoráveis são articulados nos textos do corpus. Primeiramente, o fato de os cinco enquadramentos se deslocarem do centro do gráfico em direção às bordas indica que eles costumam coocorrer entre si no corpus. Em segundo lugar, há uma quase fusão entre o enquadramento que defende as ações afirmativas raciais como medidas que diminuem as desigualdades sociais (F2) e aquele que entende que elas são importantes porque reparam os males gerados pela escravidão (F3). Essa associação discursiva se deve ao fato de que os defensores dessas políticas nos jornais se distribuem por dois grupos políticos: representantes do Estado (ministros e secretários de governo) e militantes do movimento negro. O fato de grande parte dos textos de defesa das ações afirmativas raciais ter sido produzida pelos ministros da Secretaria de Políticas da Promoção da Igualdade Racial (Seppir) fez com que ambos os enquadramentos se mesclassem em parte do corpus. Isso porque os ministros da Seppir costumaram atrelar esses dois enquadramentos em suas comunicações, de modo a promover uma perspectiva própria do movimento negro e uma retórica própria dos representantes do governo federal.

\section{Considerações Finais}

Mais do que discutir em profundidade as propriedades dos enquadramentos midiáticos detectados, o objetivo deste artigo foi apresentar um modelo analítico para a identificação de enquadramentos passível de ser utilizado por estudos ulteriores. Por se tratar de uma ferramenta conceitual interpretativa, assumiu-se o pressuposto de que a identificação de enquadramentos jamais poderá ser completamente automatizada pelos instrumentos estatísticos e informáticos disponíveis. Ainda assim, os softwares Caqdas e os modelos estatísticos para análise de dados nebulosos podem auxiliar com grande proveito a identificação de regularidades na organização do conteúdo midiático sobre um dado tema.

Há que se destacar, contudo, que a eficácia da rotina aqui proposta depende do corpus linguístico a que ela é aplicada. Uma exigência da Análise de Correspondências é que os códigos aplicados aos textos coocorram entre si. Por isso, é importante que o corpus analisado seja razoavelmente extenso e, sobretudo, possua conteúdos recorrentes. Ademais, a aplicação dessa técnica aos textos sobre ações afirmativas raciais, publicados em O Globo e na Folha de $S$. Paulo, sugere que ela é mais eficaz na identificação de enquadramentos interpretativos do que na de enquadramentos noticiosos.

De todo modo, os potenciais e limites da rotina metodológica aqui proposta dependem de experimentos futuros. Tal estratégia metodológica visa não apenas conferir maior clareza aos estudos de enquadramentos, mas, sobretudo, oferecer um remédio para a síndrome semântica que acomete a categoria. Como os próprios defensores do conceito reconhecem, a amplitude semântica da noção de enquadramento é, simultaneamente, uma qualidade heurística, pois possibilita entender com uma só categoria diferentes processos comunicativos, e um defeito, na medida em que fomenta usos imprecisos e vulgares da categoria. Embora valiosas, as diferentes tentativas de fornecer uma conceituação mais precisa para o termo não têm sido suficientes para unificar seu uso pelos estudos de mídia. Quando o objetivo é fornecer maior precisão e clareza à identificação de enquadramentos midiáticos, esforços 
CAMPOS, L. A. A identificação de enquadramentos através da análise de...

metodológicos como aquele proposto aqui são tão importantes quanto os investimentos teóricos e conceituais.

\section{Referências Bibliográficas}

Alves, J. L. "A Conferência de Durban contra o Racismo e a responsabilidade de todos". Revista Brasileira de Política Internacional, vol. 45, n², p. 198.223, 2002.

Austin, J. L. How to do things with words. Cambridge: Harvard University Press, 1962.

BAKER, C. E. Implications of rival visions of electoral campaigns. In: BenNetT, W. L.; ENTMAN, R. M. (eds.). Mediated politics: communication in the future of democracy. Cambridge. New York: Cambridge University Press, 2001.

BATESON, G. Steps to an ecology of mind: collected essays in anthropology, psychiatry, evolution, and epistemology. Northvale: Aronson, 1987.

BENZÉCRI, J.P. Correspondence analysis handbook statistics. New York: Marcel Dekker Inc., 1992.

Bourdieu, P. A distinção: crítica social do julgamento. São Paulo: Zouk e Edusp, 2007

Cappella, J.; Jamieson, K. Spiral of cynicism. Oxford: Oxford University Press, 1997.

CHONG, D.; DRUCKMAN, J. N. "A theory of framing and opinion formation in competitive elite environments". Journal of Communication, vol. 57, $n^{\circ} 1$, p. 99.118, 2007.

Entman, R. "Framing: toward clarification of a fractured paradigm". Journal of Communication, vol. 43, n 4 , p. 51.58 1993.

Gamson, W. Talking politics. New York: Cambridge University Press, 1995.

Foreword. In: ReESE, S.; GANDY JR., O. et al. (eds.). Framing public life: perspectives on media and our understanding of the social world. Mahwah, London: Lawrence Erlbaum Associates Publishers, 2001.

Gamson, W.; Modigliani, A. "The changing culture of affirmative action". Research in Political Sociology, n 3, p. 137-177, 1987.

GANDY JR., O. Epilogue - Framing at the horizon: a retrospective assessment. In: REESE, S.; GANDY JR., O. et al. (eds.). Framing public life: perspectives on media and our understanding of the social world. Mahwah, London: Lawrence Erlbaum Associates Publishers, 2001.

GITLIN, T. The whole world is watching: mass media in the making \& unmaking of the new left. Berkeley: University of California Press, 2003.

GoffMAN, E. Frame analysis: an essay on the organization of experience. Boston: Northeastern University Press, 1986.

GREENACRE, M. Correspondence analysis in practice. Boca Raton: Chapman \& Hall/CRC, 1993.

HACKETT, R. "Decline of a paradigm? Bias and objectivity in news media studies". Critical Studies in Mass Communication, vol. 1, n 3, p. 229.259, 1984.

HaLlin, D. We keep America on top of the world: television journalism and the public sphere. London; New York: Routledge, 1994.

Hallin, D.; Mancini, P. Comparing media systems: three models of media and politics. New York: Cambridge University Press, 2004

KoENIG, T. Routinizing frame analysis. In: ISA, Research Committee on Logic and Methodology RC33. Leverkusen: Leske \& Budrich, 2005

LASSWELL, H. Politics: who gets what, when, how. New York: Literary Licensing, 2011

Lazarsfeld, P. F.; Berelson, B.; Gaudet, H. The people's choice: how the voter makes up his mind in a presidential campaign. New York: Duell, 1944 
MAIA, R. "Debates públicos na mídia: enquadramentos e troca pública de razões". Revista Brasileira de Ciência Política, $n^{\circ} 2$, p. 303.340, 2009.

MccomBs, M.; SHAW, D. "The agenda-setting function of mass media". The Public Opinion Quarterly, vol. 36, n², p. 176. 187, 1972.

MENDONÇA, R. F.; SIMÕES, P. G. "Enquadramento: diferentes operacionalizações analíticas de um conceito". Revista Brasileira de Ciências Sociais, vol. 27, p. 187-201, 2012.

PereIRA, A. M. "Um raio em céu azul: reflexões sobre a política de cotas e a identidade nacional brasileira". Estudos Afro-Asiáticos, vol. 25, n 3, p. 463.482, 2003.

PoRTo, M. Enquadramentos da mídia e política. In: RuBIM, A. C. (ed.). Comunicação e política: conceitos e abordagens. Salvador; São Paulo: Edufba e Ed. Unesp, 2004.

ReESE, S. Framing public life: a bridging model for media research. In: ReESE, S.; GandY JR., O. et al. (eds.). Framing public life: perspectives on media and our understanding of the social world. Mahwah, London: Lawrence Erlbaum Associates Publishers, 2001.

SHEUfELE, D. "Framing as a theory of media effects". Journal of Communication, vol. 49, n. 1, p. 103-122, 1999.

. "Agenda-setting, priming, and framing revisited: another look at cognitive effects of political communication". Mass Communication and Society, vol. 3, n²-3, p. 297-316, 2000.

TANKARD JR., J. The empirical approach to the study of media framing. In: ReESE, S.; GANDY JR., O. et al. (eds.). Framing public life: perspectives on media and our understanding of the social world. Mahwah, London: Lawrence Erlbaum Associates Publishers, 2001.

TUCHMAN, G. "Objectivity as strategic ritual: an examination of newsmen's notions of objectivity". The American Journal of Sociology, vol. 77, n 4, p. 660-679, 1972. 131,1973

"Making news by doing work: routinizing the unexpected". American Journal of Sociology, vol. 79, n 1, p. 110. Making news: a study in the construction of reality. New York: The Free Press, 1978.

TVERSKY, A.; KahnemAn, D. "The framing of decisions and the psychology of choice". Science, n 211, p. 453.458, 1981.

VREESE, C. "News framing: theory and typology". Information Design Journal + Document Design, vol. 13, n 1, p. 51.62, 2005.

Luiz Augusto Campos · lascampos@iesp.uerj.br

Submetido à publicação setembro de 2013.

Versão final aprovada em março de 2014. 